University of Wollongong

Research Online

Australian Institute for Innovative Materials -

Papers

Australian Institute for Innovative Materials

$1-1-2014$

Enhancing the high rate capability and cycling stability of LiMn2O4 by coating of solid-state electrolyte LiNbO3

\author{
Zhijia Zhang \\ University of Wollongong, zz755@uowmail.edu.au \\ Shulei Chou \\ University of Wollongong, shulei@uow.edu.au \\ Qinfen Gu \\ Australian Synchrotron Company \\ Hua-Kun Liu \\ University of Wollongong, hua@uow.edu.au \\ Huijun Li \\ University of Wollongong, huijun@uow.edu.au
}

See next page for additional authors

Follow this and additional works at: https://ro.uow.edu.au/aiimpapers

Part of the Engineering Commons, and the Physical Sciences and Mathematics Commons

Research Online is the open access institutional repository for the University of Wollongong. For further information contact the UOW Library: research-pubs@uow.edu.au 


\title{
Enhancing the high rate capability and cycling stability of LiMn2O4 by coating of solid-state electrolyte LiNbO3
}

\author{
Abstract \\ To study the influence of solid state electrolyte coating layers on the performance of cathode materials \\ for lithium-ion batteries in combination with organic liquid electrolyte, LiNbO3 coated Li1.08Mn1.9204 \\ cathode materials were synthesized by using a facile solid-state reaction method. The \\ 0.06 LiNb03-0.97Li1.08Mn1.9204 cathode exhibited an initial discharge capacity of $125 \mathrm{mAh}$ g-1, \\ retaining a capacity of $119 \mathrm{mAh} \mathrm{g}-1$, at $25 \mathrm{oC}$, while at $55 \mathrm{oC}$, it exhibited an initial discharge capacity of \\ $130 \mathrm{mAh} \mathrm{g}-1$, retaining a capacity of $111 \mathrm{mAh} \mathrm{g}-1$, both at a current density of $0.5 \mathrm{C}$ (where $1 \mathrm{C}$ is 148 \\ mAh g-1). Very good rate capability has been demonstrated, with the 0.06LiNb03-0.97Li1.08Mn1.9204 \\ cathode showing more than $85 \%$ capacity at the rate of $50 \mathrm{C}$ compared with the capacity at $0.5 \mathrm{C}$. The \\ 0.06 LiNb03-0.97Li1.08Mn1.9204 cathode showed a high lithium diffusion coefficient $(1.6 \times 10-10 \mathrm{~cm} 2$ \\ $\mathrm{s}-1$ at $55 \mathrm{oC})$, and low apparent activation energy ( $36.9 \mathrm{~kJ}$ mol-1). The solid state electrolyte coating layer \\ is effective for preventing $\mathrm{Mn}$ dissolution and maintaining the high ionic conductivity between the \\ electrode and the organic liquid electrolyte, which may improve the design and construction of \\ nextgeneration large-scale lithium-ion batteries with high power and safety.
}

\section{Keywords}

enhancing, linbo3, coating, limn2o4, stability, electrolyte, cycling, capability, rate, state, high, solid

Disciplines

Engineering | Physical Sciences and Mathematics

\section{Publication Details}

Zhang, Z., Chou, S., Gu, Q., Liu, H., Li, H., Ozawa, K. \& Wang, J. (2014). Enhancing the high rate capability and cycling stability of LiMn2O4 by coating of solid-state electrolyte LiNbO3. ACS Applied Materials and Interfaces, 6 (24), 22155-22165.

\section{Authors}

Zhijia Zhang, Shulei Chou, Qinfen Gu, Hua-Kun Liu, Huijun Li, Kiyoshi Ozawa, and Jiazhao Wang 


\section{Enhancing the High Rate Capability and Cycling}

\section{Stability of $\mathrm{LiMn}_{2} \mathrm{O}_{4}$ by Coating of Solid-State-}

\section{Electrolyte $\mathrm{LiNbO}_{3}$}

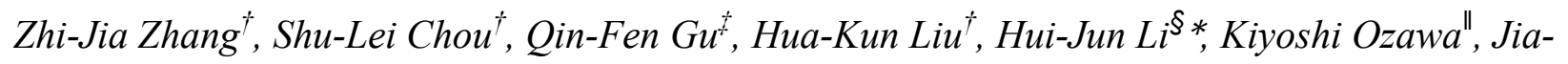
Zhao Wang $^{\dagger *}$

$\dagger$ Institute for Superconducting and Electronic Materials, University of Wollongong, Wollongong, NSW 2522, Australia;

¥Australian Synchrotron, 800 Blackburn Rd, Clayton 3168, Australia;

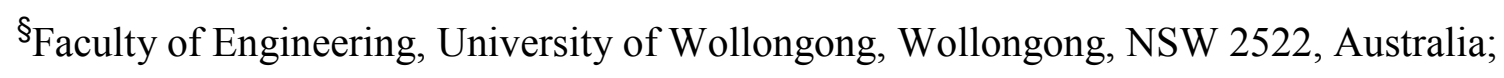

"National Institute for Materials Science, Japan

*Corresponding author: jiazhao@uow.edu.au (JZW), huijun@uow.edu.au (HJL)

Telephone: +61 24298 1478; Fax: +61242215731 
ABSTRACT: To study the influence of solid state electrolyte coating layers on the performance of cathode materials for lithium-ion batteries in combination with organic liquid electrolyte, $\mathrm{LiNbO}_{3}$ coated $\mathrm{Li}_{1.08} \mathrm{Mn}_{1.92} \mathrm{O}_{4}$ cathode materials were synthesized by using a facile solid-state reaction method. The $0.06 \mathrm{LiNbO}_{3}-0.97 \mathrm{Li}_{1.08} \mathrm{Mn}_{1.92} \mathrm{O}_{4}$ cathode exhibited an initial discharge capacity of $125 \mathrm{mAh} \mathrm{g}^{-1}$, retaining a capacity of $119 \mathrm{mAh} \mathrm{g}^{-1}$, at $25{ }^{\circ} \mathrm{C}$, while at $55{ }^{\circ} \mathrm{C}$, it exhibited an initial discharge capacity of $130 \mathrm{mAh} \mathrm{g}^{-1}$, retaining a capacity of $111 \mathrm{mAh} \mathrm{g}^{-1}$, both at a current density of $0.5 \mathrm{C}$ (where $1 \mathrm{C}$ is $148 \mathrm{mAh} \mathrm{g}^{-1}$ ). Very good rate capability has been demonstrated, with the $0.06 \mathrm{LiNbO}_{3}-0.97 \mathrm{Li}_{1.08} \mathrm{Mn}_{1.92} \mathrm{O}_{4}$ cathode showing more than $85 \%$ capacity at the rate of $50 \mathrm{C}$ compared with the capacity at $0.5 \mathrm{C}$. The $0.06 \mathrm{LiNbO}_{3}-0.97 \mathrm{Li}_{1.08} \mathrm{Mn}_{1.92} \mathrm{O}_{4}$ cathode showed a high lithium diffusion coefficient $\left(1.6 \times 10^{-10} \mathrm{~cm}^{2} \mathrm{~s}^{-1}\right.$ at $\left.55{ }^{\circ} \mathrm{C}\right)$, and low apparent activation energy $\left(36.9 \mathrm{~kJ} \mathrm{~mol}^{-1}\right)$. The solid state electrolyte coating layer is effective for preventing Mn dissolution and maintaining the high ionic conductivity between the electrode and the organic liquid electrolyte, which may improve the design and construction of nextgeneration large-scale lithium-ion batteries with high power and safety.

KEYWORDS: $\mathrm{LiMn}_{2} \mathrm{O}_{4} ; \mathrm{LiNbO}_{3}$; solid state electrolyte layer; in situ synchrotron XRD; cathode materials; lithium-ion batteries 


\section{Introduction}

As one of the most promising candidates for power sources in electric vehicles (EVs) and hybrid electric vehicles (HEVs), lithium-ion batteries (LIBs) need to be further improved by solving problems related to safety issues, high costs, low rate capability, and low energy density. ${ }^{1-3}$ Cathode materials play a decisive role in LIBs because they can contribute to low cost, as well as high energy and high power densities. Lithium manganese oxide with a spinel structure has been widely studied as a promising candidate cathode for safe and high power LIBs, and $\mathrm{Li}_{1-x} \mathrm{Mn}_{2-y} \mathrm{O}_{4}$ with the proper degree of cation mixing [excess lithium atom $(x<0.1)$ occupying the manganese sites (16 sites) and Mn ions in the tetrahedral sites ( 8 sites) in the spinel structure] has shown high cycling performance. ${ }^{4-7}$ It remains challenging, however, to control capacity decay during cycling, which is well-known to be associated with Mn dissolution via the disproportionation reaction $\left(2 \mathrm{Mn}^{3+}\right.$ (solid) $\rightarrow \mathrm{Mn}^{4+}$ (solid) $+\mathrm{Mn}^{2+}$ (solution) $)$ and the crystallographic structural transformation from cubic to tetragonal phase by Jahn-Teller distortion of $\mathrm{Mn}^{3+}$ ions with high spin. ${ }^{8-10}$ Meanwhile, organic liquid electrolyte (OLE) is another reason for the restricted development of large-scale batteries, because it is flammable and prone to the growth of lithium dendrites. ${ }^{11-13}$ Solid state electrolyte (SSE) has been proposed to replace the OLE, because it simplifies the battery design and increases the lifetime and safety of the batteries. ${ }^{14-17}$ SSE is handicapped by several crucial problems for battery applications, however, relating to the Li-ion transference number, mechanical strength, and electrode/electrolyte interface contact. ${ }^{18-20}$ Therefore, combining the advantages of the SSE and OLE is a possible solution for designing next-generation large-scale LIBs with lithium manganese oxide cathode.

For combining the advantages of the cathode, SSE, and OLE, one viable option is modification of the electrode by surface coating, which is a popular and highly effective method 
to achieve improved electrochemical performance. Usually, oxides $\left(\mathrm{MgO},{ }^{21} \mathrm{Al}_{2} \mathrm{O}_{3},{ }^{22} \mathrm{SiO}_{2},{ }^{23}\right.$ $\mathrm{ZrO}_{2}{ }^{24}$ ), polymers (polypyrrole (PPy), ${ }^{25}$ polyacrylonitrile $\left.(\mathrm{Pan})^{26}\right)$, and different forms of carbon (amorphous carbon, ${ }^{27}$ graphene, ${ }^{28}$ graphite ${ }^{29}$ ) are used as coating layers. The coating layers can: (1) prevent direct contact with the electrolyte solution, (2) suppress phase transitions and/or prevent dendrite growth, (3) improve the structural stability, and (4) decrease the disorder of cations in crystal sites, but at the expense of compromising the theoretical capacity and/or the energy density. ${ }^{30}$

Furthermore, as a coating layer on the electrode surface, SSE is required to have easy synthesis and a simple structure. $\mathrm{LiNbO}_{3}$, a kind of SSE, can be synthesized by solid state reaction and has the $R 3 c$ crystal structure. Glass et al. reported that $\mathrm{LiNbO}_{3}$ could be considered as a SSE in 1978, because it exhibits high room-temperature ionic conductivity and low electronic conductivity $\left(10^{-5} \mathrm{~S} \mathrm{~cm}^{-1}\right.$ and $10^{-11} \mathrm{~S} \mathrm{~cm}^{-1}$, respectively). ${ }^{31}$ Recently, Ohta et al. ${ }^{32}$ reported that $\mathrm{LiNbO}_{3}$ could be applied in all-solid-state lithium secondary batteries as the buffer layer between the $\mathrm{LiCoO}_{2}$ cathode and the sulphide electrolyte $\left(\mathrm{Li}_{3.25} \mathrm{Ge}_{0.25} \mathrm{P}_{0.75} \mathrm{~S}_{4}\right.$, denoted as thio-LISICON), due to its high ionic conductivity and ease of synthesis and coating on the $\mathrm{LiCoO}_{2}$ cathode surface. The resultant battery exhibited low interfacial resistance and high-rate capability, as well as revealing a feasible method to increase the ionic conductivity at the interface between the electrode and the bulk SSE.

As an attempt to introduce an SSE coating layer into LIBs in combination with OLE, herein, we have developed a novel LIB system which consists of a manganese spinel cathode, an $\mathrm{SSE} \mathrm{LiNbO}_{3}$-coating layer, OLE, and a lithium foil anode (Figure 1). In this report, $\mathrm{LiNbO}_{3}$ coated- $\mathrm{Li}_{1.08} \mathrm{Mn}_{1.92} \mathrm{O}_{4}$ was synthesized by a simple solid-state reaction method. The influence of the $\mathrm{LiNbO}_{3}$ coating layer on the $\mathrm{Li}_{1.08} \mathrm{Mn}_{1.92} \mathrm{O}_{4}$ spinel cathode has been investigated, including 
the influence on the crystal structure and electrochemical performance. The $\mathrm{SSE} \mathrm{LiNbO}_{3}$-coating layer effectively prevents Mn dissolution and maintains the high ionic conductivity between the OLE and the cathode.

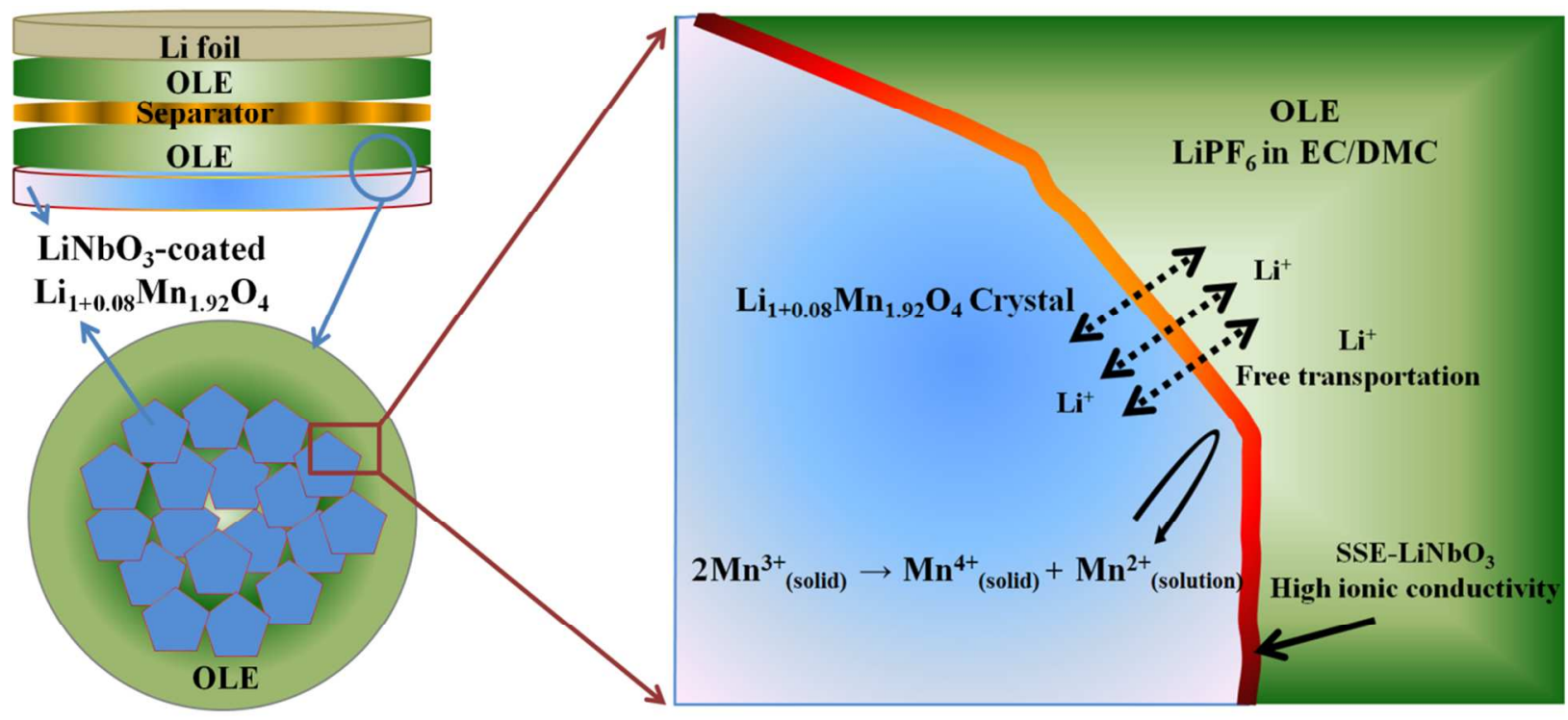

Figure 1. Schematic illustration of cathode-electrolyte interface in a lithium-ion battery containing both an $\mathrm{SSE}-\mathrm{LiNbO}_{3}$ coating layer and organic liquid electrolyte. OLE: organic liquid electrolyte; SSE: solid state electrolyte; EC: ethylene carbonate; DMC: dimethyl carbonate.

\section{Experimental Section}

Synthesis: $\quad$ The $\mathrm{LiNbO}_{3}$-coated $\mathrm{Li}_{1.08} \mathrm{Mn}_{1.92} \mathrm{O}_{4}$ composite materials were synthesized by solidstate reaction. The starting materials, niobium pentoxide $\left(\mathrm{Nb}_{2} \mathrm{O}_{5}, 99.8 \%\right.$ purity, CBMM-Brazil), lithium carbonate $\left(\mathrm{LiCO}_{3}, \geq 99 \%\right.$ purity, Sigma-Aldrich), and manganese acetate $\left(\mathrm{Mn}\left(\mathrm{CH}_{3} \mathrm{COO}\right)_{2} \cdot 4 \mathrm{H}_{2} \mathrm{O}, \geq 99 \%\right.$ purity, Sigma-Aldrich) were ground in an agate mortar with a pestle in the predetermined ratio $\mathrm{Nb}: \mathrm{Li}: \mathrm{Mn}=x: 1.15: 1.92-x(x=0,0.03,0.06,0.1)$ until the mixture became homogeneous. After that, the mixture was pressed into pellets and preheated at 
$650{ }^{\circ} \mathrm{C}$ in air for $5 \mathrm{~h}$ in a tube furnace. Then, the mixture was again ground, pressed into pellets, and heated at $750{ }^{\circ} \mathrm{C}$ in air for $24 \mathrm{~h}$ in the same tube furnace. All the samples were cooled to room temperature at the cooling rate of $1{ }^{\circ} \mathrm{C} / \mathrm{min}$ after the second heat-treatment. The details of the compositions and synthesis conditions for the $\mathrm{LiNbO}_{3}$-coated $\mathrm{Li}_{1.08} \mathrm{Mn}_{1.92} \mathrm{O}_{4}$ composite materials are summarized in Table 1.

Table 1. Summary of preparation conditions for $x^{*} \mathrm{LiNbO}_{3}-(1-x / 2) \mathrm{Li}_{1.08} \mathrm{Mn}_{1.92} \mathrm{O}_{4}$ composite materials.

\begin{tabular}{lllll}
\hline Sample & $\mathrm{Nb} / \mathrm{Li} / \mathrm{Mn}$ ratio & \multicolumn{1}{l}{ Target composite } & \multicolumn{2}{l}{ Preparation conditions } \\
\cline { 3 - 5 } & $\mathrm{x}: 1.1: 1.92-\mathrm{x}$ & $\mathrm{xLiNbO}-(1-\mathrm{x} / 2) \mathrm{Li}_{1.08} \mathrm{Mn}_{1.92} \mathrm{O}_{4}$ & Preheating & 2nd heating \\
\hline $\mathrm{x}=0$ & $0: 1.1: 1.92$ & $\mathrm{Li}_{1.08} \mathrm{Mn}_{1.92} \mathrm{O}_{4}$ & $650{ }^{\circ} \mathrm{C}$ for $5 \mathrm{~h}$ & $750{ }^{\circ} \mathrm{C}$ for $24 \mathrm{~h}$ \\
$\mathrm{x}=0.03$ & $0.03: 1.1: 1.89$ & $0.03 \mathrm{LiNbO}_{3}-0.985 \mathrm{Li}_{1.08} \mathrm{Mn}_{1.92} \mathrm{O}_{4}$ & $650^{\circ} \mathrm{C}$ for $5 \mathrm{~h}$ & $750{ }^{\circ} \mathrm{C}$ for $24 \mathrm{~h}$ \\
$\mathrm{x}=0.06$ & $0.06: 1.1: 1.86$ & $0.06 \mathrm{LiNbO}_{3}-0.97 \mathrm{Li}_{1.08} \mathrm{Mn}_{1.92} \mathrm{O}_{4}$ & $650^{\circ} \mathrm{C}$ for $5 \mathrm{~h}$ & $750^{\circ} \mathrm{C}$ for $24 \mathrm{~h}$ \\
$\mathrm{x}=0.1$ & $0.1: 1.1: 1.82$ & $0.1 \mathrm{LiNbO}_{3}-0.95 \mathrm{Li}_{1.08} \mathrm{Mn}_{1.92} \mathrm{O}_{4}$ & $650^{\circ} \mathrm{C}$ for $5 \mathrm{~h}$ & $750^{\circ} \mathrm{C}$ for $24 \mathrm{~h}$ \\
\hline
\end{tabular}

$x$ is mol ratio of $\mathrm{LiNbO}_{3}$ in $\mathrm{LiNbO}_{3}$ coated $-\mathrm{Li}_{1.08} \mathrm{Mn}_{1.92} \mathrm{O}_{4}$

Characterization: The structures and morphologies of the as-prepared materials were characterized by X-ray diffraction (XRD; GBC MMA) with $\mathrm{Cu} \mathrm{K} \alpha$ radiation, synchrotron X-ray diffraction (SXRD) with in situ SXRD conducted at the Powder Diffraction Beamline (wavelengths: $0.7747 \AA$, and $0.6888 \AA$; Australian Synchrotron, Clayton, Australia) with a Mythen detector, field emission scanning electron microscopy (FESEM; JEOL 7500, $30 \mathrm{kV}$ ), transmission electron microscopy (TEM; JEOL JEM-2011, $200 \mathrm{kV}$ ) with high-resolution TEM (HRTEM), and Brunauer-Emmett-Teller (BET) analysis (Quanta Chrome Nova 1000). To test the electrodes after cycling, the cells were opened, and the electrodes were taken out and washed with dimethyl carbonate (DMC) three times. For the in situ synchrotron X-ray diffraction, Kapton film was used as a window to allow the penetration of the synchrotron beam into the in situ cell, which was assembled under the same conditions as the other cells in this work. 
Electrochemical measurements: $\quad$ To test the electrochemical performance, the electrodes were prepared by mixing $x \mathrm{LiNbO}_{3}-(1-x / 2) \mathrm{Li}_{1.08} \mathrm{Mn}_{1.92} \mathrm{O}_{4}(x=0,0.03,0.06$, or 0.1$)$ composite materials with acetylene black (AB) and polyvinylidene fluoride (PVDF) in $N$-methyl-2pyrrolidone (NMP), with a weight ratio of $80: 10: 10$. The slurry was spread onto aluminum foil substrates with an area of $1 \times 1 \mathrm{~cm}^{2}$ and dried at $100{ }^{\circ} \mathrm{C}$ in a vacuum oven for $24 \mathrm{~h}$ to remove water molecules. The electrode was then pressed using a disc with a diameter of $14 \mathrm{~mm}$ to enhance the contact between the aluminum foil, active materials, and conductive carbon. The average active material loading rate was $\sim 5 \mathrm{mg} \mathrm{cm}^{-2}$. CR 2032 coin-type cells were assembled in an Ar-filled glove box (Mbraun, Unilab, Germany), using lithium metal foil as the counter electrode. The electrolyte was $1 \mathrm{M} \mathrm{LiPF}_{6}$ in a mixture of ethylene carbonate (EC) and dimethyl carbonate (DMC) (1:1 by volume, provided by MERCK KGaA, Germany). The cells were galvanostatically charged and discharged in the voltage range of 4.5-3.2 $\mathrm{V}$ at different current densities using a computer-controlled charger system manufactured by Land Battery Testers. A Biologic VMP-3 electrochemical work station was used to perform cyclic voltammetry (CV; scanning rate $0.1 \mathrm{mV} \mathrm{s}^{-1}$ ) and electrochemical impedance spectroscopy (EIS; ac amplitude $5 \mathrm{mV}$, frequency range $100 \mathrm{kHz}-0.01 \mathrm{~Hz})$.

\section{Results and discussion}

The structures and phases of the as-prepared $x \mathrm{LiNbO}_{3}-(1-x / 2) \mathrm{Li}_{1.08} \mathrm{Mn}_{1.92} \mathrm{O}_{4}(x=0,0.03$, 0.06, and 0.1) samples were analyzed by XRD (Figure S1 in the Supporting Information) and SXRD (Figure 2 and Figure S2). The diffraction patterns can be indexed as mixed phases with a slight amount of peak shifting compared with the standards in the database $\left[\mathrm{LiMn}_{2} \mathrm{O}_{4} F d \overline{\mathbf{3}} m\right.$ spinel structure (JPCDS card no. 35-0782) and $\mathrm{LiNbO}_{3} R 3 c$ structure (JPCDS card no. 200631)]. As can be seen from SXRD Rietveld refinement results in Figure 2a, the spinel 
$\mathrm{Li}_{1.08} \mathrm{Mn}_{1.92} \mathrm{O}_{4}$ sample can be written as $\mathrm{Li}_{1.079} \mathrm{Mn}_{1.920} \mathrm{O}_{4}$, matching well with the target value (Table 2 and Tables $\mathrm{S} 1-\mathrm{S} 5$ ). After the $\mathrm{Nb}$ element is added, the $\mathrm{LiNbO}_{3}$ phase materials maintains a stable structure and the lattice constant of $\mathrm{Li}_{1.08} \mathrm{Mn}_{1.92} \mathrm{O}_{4}$ compared with $\mathrm{LiMn}_{2} \mathrm{O}_{4}$ is slightly increased, corresponding to the partial replacement by lithium ions of manganese ions in octahedral sites (lattice parameter details shown in Table S1). ${ }^{33,34}$ It needs to be pointed out, however, that the refined formula for $0.1 \mathrm{LiNbO}_{3}-0.95 \mathrm{Li}_{1.08} \mathrm{Mn}_{1.92} \mathrm{O}_{4}$ composite material cannot match the target value, indicating that the amount of $\mathrm{LiNbO}_{3}$ should be less than 0.1 mol for maintaining effective cation mixing in $\mathrm{Li}_{1-x} \mathrm{Mn}_{2-x} \mathrm{O}_{4}$ (Table 1). ${ }^{35-37}$ As shown in Table 2, the amount of lithium ions is less than $1.15 \mathrm{~mol}$. The small amount of lithium ion loss in the composite is owing to the natural presence of lithium vapor at around $650{ }^{\circ} \mathrm{C} .{ }^{38}$ The vapor component of the lithium ions can react with niobium ions when the amount of niobium is high enough, according to the results of Table 2 .

Table 2. Rietveld refinement results based on $\mathrm{SXRD}$ data for $x \mathrm{LiNbO}_{3}-(1-\mathrm{x} / 2) \mathrm{Li}_{1.08} \mathrm{Mn}_{1.92} \mathrm{O}_{4}(x$ $=0,0.03,0.06,0.1)$ composite materials.

\begin{tabular}{lll}
\hline Sample & Composite formula & $\mathrm{Nb} / \mathrm{Li} / \mathrm{Mn}$ ratio \\
\hline $\mathrm{x}=0$ & $\mathrm{Li}_{1.079} \mathrm{Mn}_{1.920} \mathrm{O}_{4}$ & $0: 1.079: 1.920$ \\
$\mathrm{x}=0.03$ & $0.029 \mathrm{LiNbO}_{3}-0.986 \mathrm{Li}_{1.072} \mathrm{Mn}_{1.928} \mathrm{O}_{4}$ & $0.029: 1.057: 1.901$ \\
$\mathrm{x}=0.06$ & $0.060 \mathrm{LiNbO}_{3}-0.970 \mathrm{Li}_{1.087} \mathrm{Mn}_{1.912} \mathrm{O}_{4}$ & $0.060: 1.054: 1.855$ \\
$\mathrm{x}=0.1$ & $0.089 \mathrm{LiNbO}_{3}-0.956 \mathrm{Li}_{1.099} \mathrm{Mn}_{1.901} \mathrm{O}_{4}$ & $0.089: 1.051: 1.817$ \\
\hline
\end{tabular}




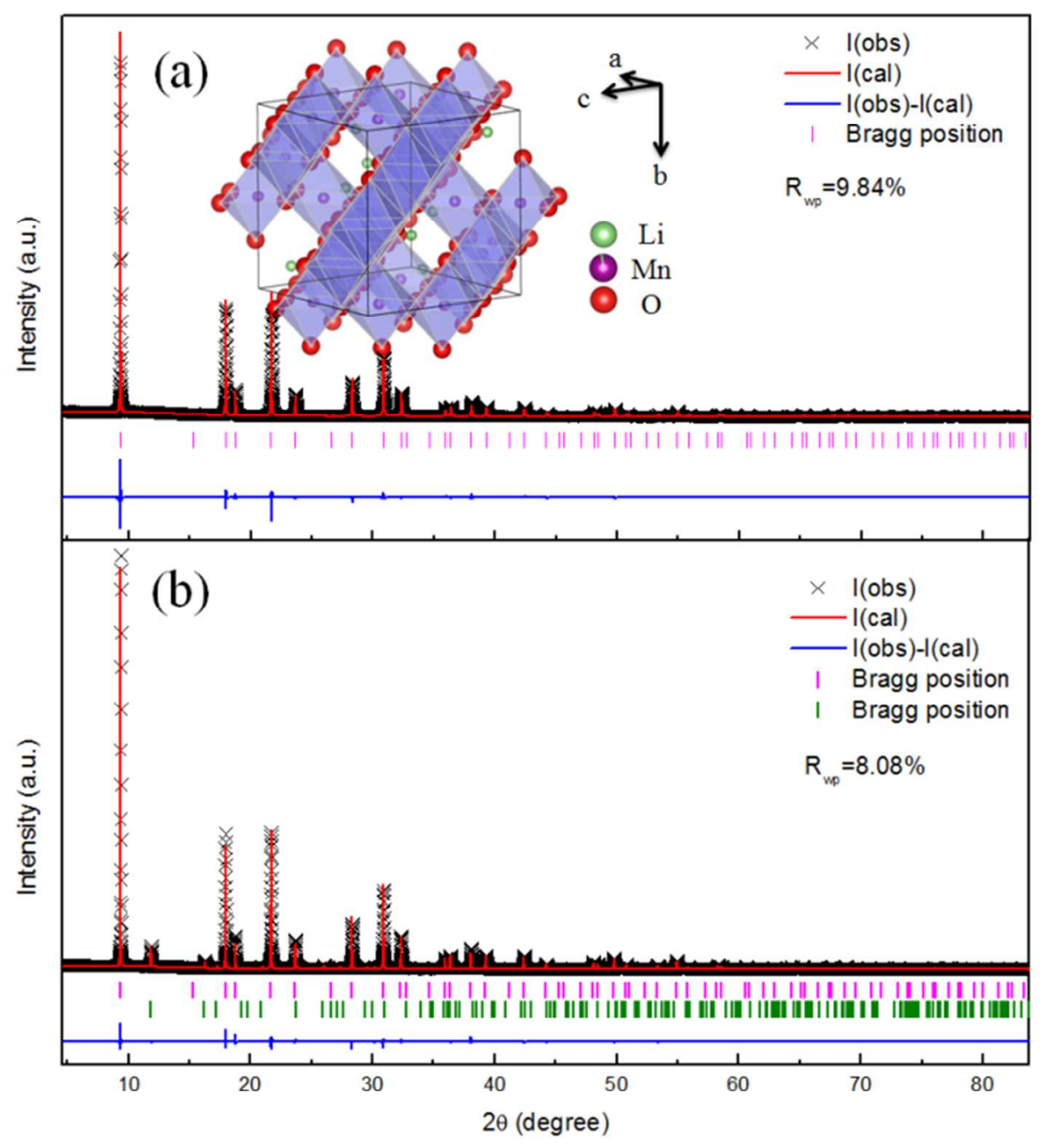

Figure 2. Rietveld refined $\mathrm{SXRD}$ patterns of (a) $\mathrm{Li}_{1.08} \mathrm{Mn}_{1.92} \mathrm{O}_{4}$, with the spinel structure of $\mathrm{Li}_{1.08} \mathrm{Mn}_{1.92} \mathrm{O}_{4}$ shown in the inset (space group $F d \overline{3} m$ ); (b) $0.06 \mathrm{LiNbO}_{3}-0.97 \mathrm{Li}_{1.08} \mathrm{Mn}_{1.92} \mathrm{O}_{4}$. $\mathrm{I}(\mathrm{obs})$ is observed data, $\mathrm{I}(\mathrm{cal})$ is calculated data, $\mathrm{I}(\mathrm{obs})-\mathrm{I}(\mathrm{cal})$ is the difference curve between the observed and calculated intensities. $R_{\mathrm{wp}}$ is the weighted profile factor.

Typical FESEM and TEM observations of the $x \mathrm{LiNbO}_{3}-(1-\mathrm{x} / 2) \mathrm{Li}_{1.08} \mathrm{Mn}_{1.92} \mathrm{O}_{4}(x=0$, 0.03, 0.06, and 0.1) composite materials are shown in Figure S3 and S4. The particles of the pristine $\mathrm{Li}_{1.08} \mathrm{Mn}_{1.92} \mathrm{O}_{4}$ sample showed very smooth edges, and there is no other layer on the 
surface. After introducing the $\mathrm{Nb}$ element, the particle sizes of the $x \mathrm{LiNbO}_{3}-(1-$ $\mathrm{x} / 2) \mathrm{Li}_{1.08} \mathrm{Mn}_{1.92} \mathrm{O}_{4}(x=0.03,0.06,0.1)$ composite materials are slightly increased, however, the particle sizes gradually decrease as the amount of $\mathrm{Nb}$ element increases, and the $0.06 \mathrm{LiNbO}_{3}$ $0.97 \mathrm{Li}_{1.08} \mathrm{Mn}_{1.92} \mathrm{O}_{4}$ composite material features an almost uniform coating layer on the surface of the $\mathrm{Li}_{1.08} \mathrm{Mn}_{1.92} \mathrm{O}_{4}$ particles. The specific surface areas of the as-prepared samples were measured by the 15-point Brunauer-Emmett-Teller (BET) $\mathrm{N}_{2}$ adsorption method. The specific surface areas of the $x \mathrm{LiNbO}_{3}-(1-\mathrm{x} / 2) \mathrm{Li}_{1.08} \mathrm{Mn}_{1.92} \mathrm{O}_{4}(x=0,0.03,0.06$, and 0.1$)$ composite materials were 2.9, 1.8, 2.3, and $2.5 \mathrm{~m}^{2} \mathrm{~g}^{-1}$, respectively. The specific surface areas of the $\mathrm{LiNbO}_{3}$ coated samples are lower than for the sample without $\mathrm{LiNbO}_{3}$, because the $\mathrm{LiNbO}_{3}$ coating layer acts as a connecting layer between some tiny $\mathrm{Li}_{1.08} \mathrm{Mn}_{1.92} \mathrm{O}_{4}$ particles.

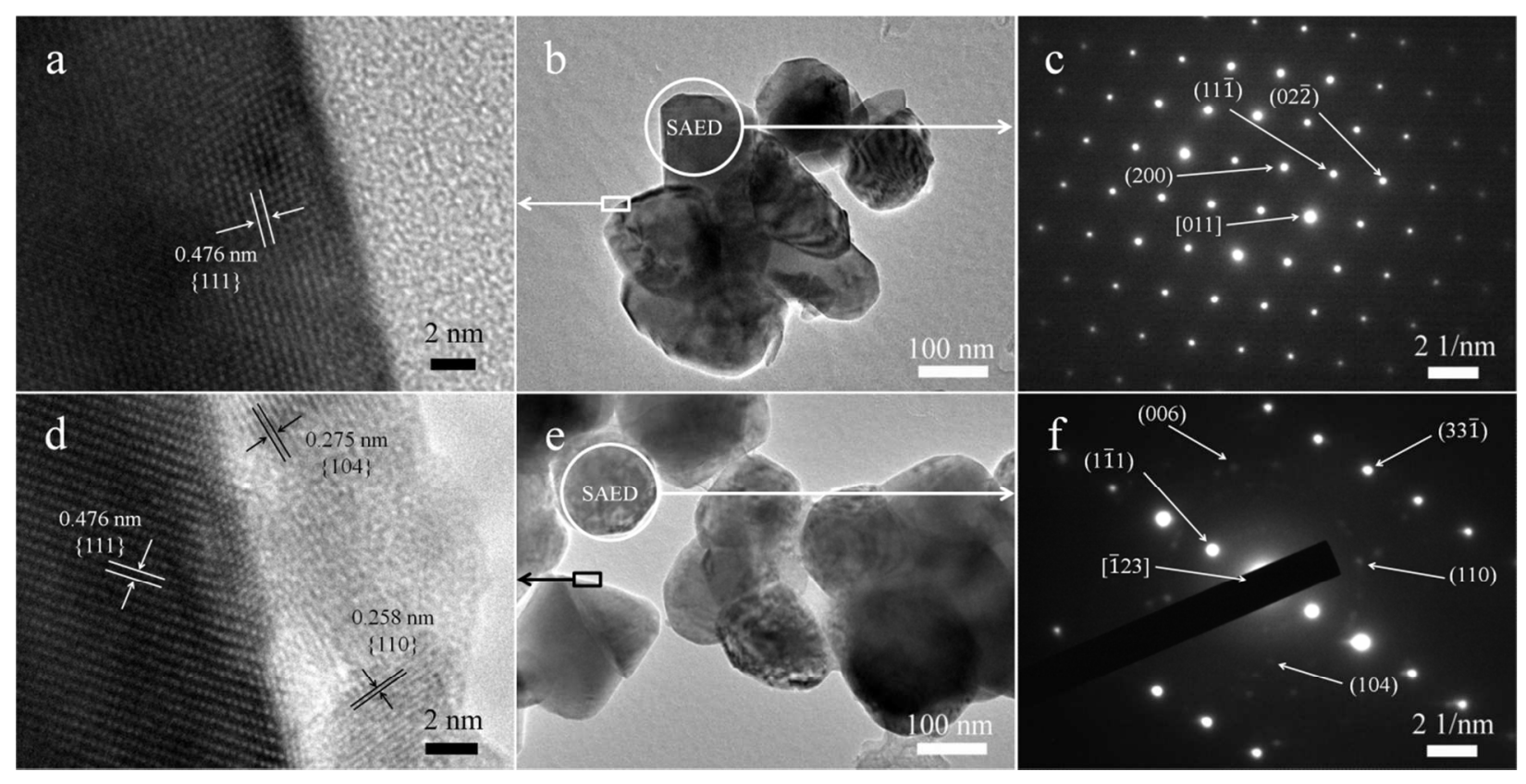

Figure 3. HRTEM images of a) $\mathrm{Li}_{1.08} \mathrm{Mn}_{1.92} \mathrm{O}_{4}$ and d) $0.06 \mathrm{LiNbO}_{3}-0.97 \mathrm{Li}_{1.08} \mathrm{Mn}_{1.92} \mathrm{O}_{4}$; b) and f) are the corresponding low magnification TEM images; c) and f) are the corresponding SAED patterns. 
To confirm the thickness and crystal structure of the coating layer and matrix, HRTEM images and the corresponding electron diffraction patterns are shown in Figure 3. The pristine $\mathrm{Li}_{1.08} \mathrm{Mn}_{1.92} \mathrm{O}_{4}$ sample shows lattice fringes with a lattice spacing of $4.76 \AA$ along the [111] direction, and the selected area electron diffraction (SAED) pattern presents well-defined spots which can be well indexed to the cubic spinel structure [Figure 3(a-c)]. As observed in Figure 3(d), the thickness of the $\mathrm{LiNbO}_{3}$ coating layer is $5-8 \mathrm{~nm}$, and the $\mathrm{LiNbO}_{3}$ coating layer consists of nanocrystalline structures with different crystallographic directions (such as the [104] direction with a lattice spacing of $2.75 \AA$ and the [110] direction with a lattice spacing of 2.58 $\AA$ ). Furthermore, the SAED pattern for the $0.06 \mathrm{LiNbO}_{3}-0.97 \mathrm{Li}_{1.08} \mathrm{Mn}_{1.92} \mathrm{O}_{4}$ composite material clearly shows two sets of diffraction spots: 1) well-defined bright spots indexed to the cubic spinel structure; 2) polycrystalline diffraction rings corresponding to the $\mathrm{LiNbO}_{3}$ coating layer and indexed as (104), (110), and (006) from the inside out, respectively [Figure 3(e) and (f)]. Therefore, it is found that the $0.06 \mathrm{LiNbO}_{3}-0.97 \mathrm{Li}_{1.08} \mathrm{Mn}_{1.92} \mathrm{O}_{4}$ composite material has the proper concentration of $\mathrm{Nb}$ element, with a thin and uniform $\mathrm{LiNbO}_{3}$ coating layer acquired during the solid-state reaction. The solid-state reaction should consist of a two-phase synergistic nucleation and growth process and the small amount of $\mathrm{LiNbO}_{3}$ has a preference for nucleation and growth at $\mathrm{Li}_{1.08} \mathrm{Mn}_{1.92} \mathrm{O}_{4}$ lattice defects which are located at the crystal surface.

The influence of the SSE-coating layer on LIBs was investigated as follows. The electrochemical performance of the $x \mathrm{LiNbO}_{3}-(1-\mathrm{x} / 2) \mathrm{Li}_{1.08} \mathrm{Mn}_{1.92} \mathrm{O}_{4}(x=0,0.03,0.06,0.1)$ composite materials was initially investigated by cyclic voltammetry (CV) (Figure S5). In all of the four samples, the typical two redox peaks can be observed, corresponding to a two-step reversible intercalation reaction, leading to $\lambda-\mathrm{MnO}_{2} / \mathrm{Li}_{0.5} \mathrm{Mn}_{2} \mathrm{O}_{4}$ and $\mathrm{Li}_{0.5} \mathrm{Mn}_{2} \mathrm{O}_{4} / \mathrm{LiMn}_{2} \mathrm{O}_{4} \cdot{ }^{39-41}$ Meanwhile, apart from the first cycle (electrode activation), no significant alteration in the $\mathrm{CV}$ 
curves is observed from the second cycle onwards. An additional peak at $3.8 \mathrm{~V}-3.9 \mathrm{~V}$ appears in Figure S5(a-c). Chen's group reported that the peak at $3.8 \mathrm{~V}-3.9 \mathrm{~V}$ is caused by the disordered structure of the lithium-rich spinel manganese oxide and that this peak is present in the first discharge curve. ${ }^{42}$ Tarascon's group also reported that the cation mixing in spinel $\mathrm{LiMn}_{2} \mathrm{O}_{4}$ between lithium octahedral sites ( 8 sites) and manganese tetrahedral sites (16 sites), gives rise to high discharge capacity. ${ }^{35}$ As can be seen from the $x \mathrm{LiNbO}_{3}-(1-\mathrm{x} / 2) \mathrm{Li}_{1.08} \mathrm{Mn}_{1.92} \mathrm{O}_{4}(x$ $=0.03$ and 0.06 ) electrodes [Figure S5(b) and (c)], the peak at 3.8 V - 3.9 V shows no significant alteration from the second cycle onwards. The reason might be that the $\mathrm{SSE}-\mathrm{LiNbO}_{3}$ coating layer prevents change in the disordered structure.

Charge/discharge curves for the first cycle are shown in Figure 4(a). In good agreement with the $\mathrm{CV}$ results, all of the $x \mathrm{LiNbO}_{3}-(1-x / 2) \mathrm{Li}_{1.08} \mathrm{Mn}_{1.92} \mathrm{O}_{4}$ electrodes show two distinguishable pseudoplateaus (at $\sim 4.15 \mathrm{~V}$ and $\sim 4.0 \mathrm{~V}$ ) and the $0.06 \mathrm{LiNbO}_{3}-0.97 \mathrm{Li}_{1.08} \mathrm{Mn}_{1.92} \mathrm{O}_{4}$ electrode shows an extra plateau at $3.8 \mathrm{~V}-3.9 \mathrm{~V}$, resulting in a higher discharge capacity than for the other SSE-coated electrodes (126.1 $\mathrm{mAh} \mathrm{g}^{-1}, 124.9 \mathrm{mAh} \mathrm{g}^{-1}$, and $119.1 \mathrm{mAh} \mathrm{g}^{-1}$, corresponding to $x=0.03,0.06$, and 0.1 , respectively). The pristine $\mathrm{Li}_{1.08} \mathrm{Mn}_{1.92} \mathrm{O}_{4}$ electrode shows the highest discharge capacity with $131.5 \mathrm{mAh} \mathrm{g}^{-1}$, agreeing well with those of other reported lithium-rich manganese oxides. ${ }^{37,43,44}$ To further evaluate the rate capability, the $x \mathrm{LiNbO}_{3}-(1-x / 2) \mathrm{Li}_{1.08} \mathrm{Mn}_{1.92} \mathrm{O}_{4}$ electrodes were cycled at various current densities ranging from $0.5 \mathrm{C}$ to $50 \mathrm{C}$ within a potential window of $4.5-3.2 \mathrm{~V}$ at $25{ }^{\circ} \mathrm{C}$, followed by a return to $0.5 \mathrm{C}$. A rate of $n \mathrm{C}$ corresponds to a full charge/discharge rate of the theoretical capacity in $1 / n$ hours, and $1 \mathrm{C}$ is $148 \mathrm{mAh} \mathrm{g}^{-1}$ for $\mathrm{LiMn}_{2} \mathrm{O}_{4}$. As shown in Figure $4(\mathrm{~b})$ and (c), the $0.03 \mathrm{LiNbO}_{3}$ 0.985 $\mathrm{Li}_{1.08} \mathrm{Mn}_{1.92} \mathrm{O}_{4}$ electrode and $0.06 \mathrm{LiNbO}_{3}-0.97 \mathrm{Li}_{1.08} \mathrm{Mn}_{1.92} \mathrm{O}_{4}$ electrode exhibit excellent rate capability, such that when the C-rate increases, even up to $50 \mathrm{C}$, the cell still retains $83.3 \%$ and 
$87.9 \%$ of the original capacity of $124.9 \mathrm{mAh} \mathrm{g}^{-1}$ and $126.1 \mathrm{mAh} \mathrm{g}^{-1}$, respectively. Whereas, the pristine
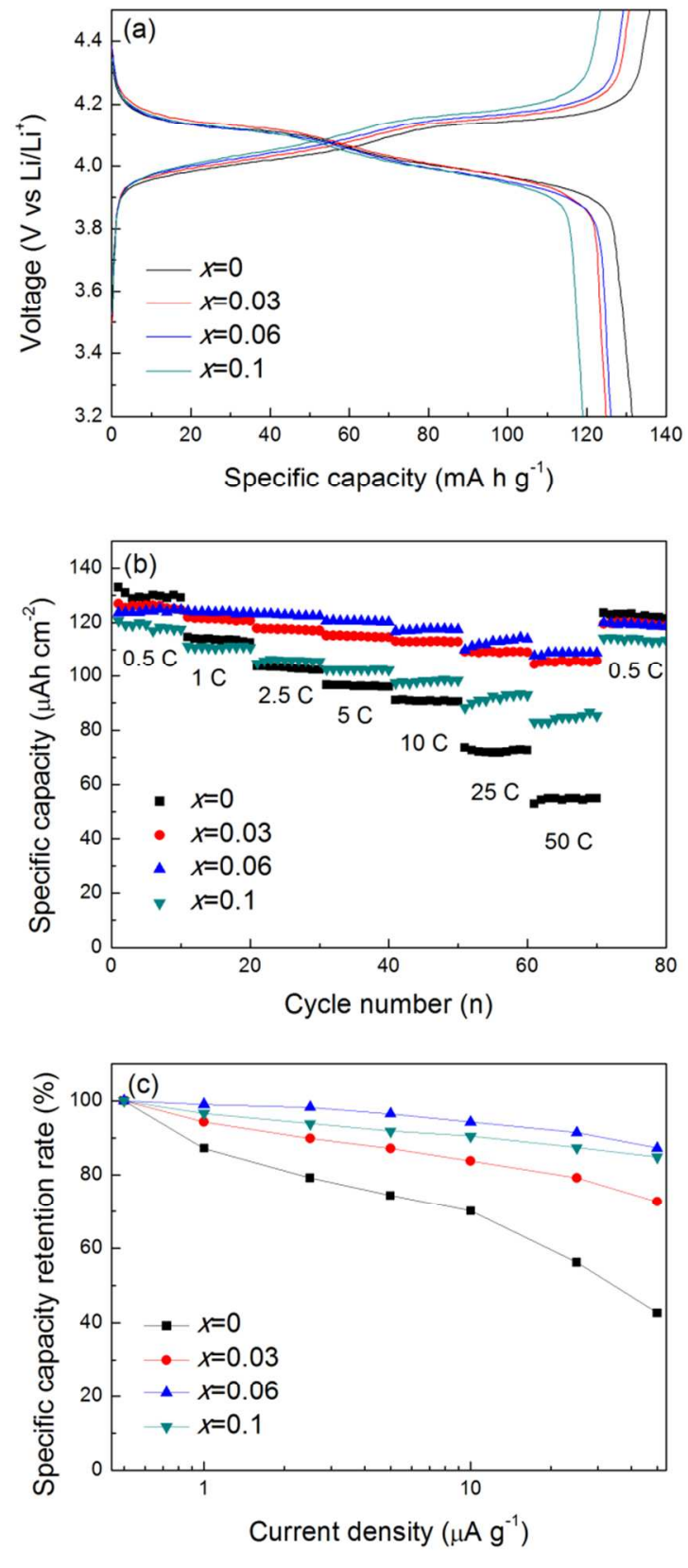

Figure 4. (a) Charge-discharge curves of $x \mathrm{LiNbO}_{3}-(1-x / 2) \mathrm{Li}_{1.08} \mathrm{Mn}_{1.92} \mathrm{O}_{4}$ electrodes for the first cycle at $25{ }^{\circ} \mathrm{C}$ at current density of $0.5 \mathrm{C}\left(1 \mathrm{C}=148 \mathrm{mAh} \mathrm{g}^{-1}\right)$; (b) rate performance and (c) capacity retention rate of $x \mathrm{LiNbO}_{3}-(1-x / 2) \mathrm{Li}_{1.08} \mathrm{Mn}_{1.92} \mathrm{O}_{4}$ electrodes at different current densities 
from $0.5 \mathrm{C}$ to $50 \mathrm{C}$ at $25^{\circ} \mathrm{C}$. The rate capability in (c) is expressed as a relative specific discharge rate compared to that obtained at the low rate of $0.5 \mathrm{C}$.

$\mathrm{Li}_{1.08} \mathrm{Mn}_{1.92} \mathrm{O}_{4}$ electrode and the $0.1 \mathrm{LiNbO}_{3}-0.95 \mathrm{Li}_{1.08} \mathrm{Mn}_{1.92} \mathrm{O}_{4}$ electrode show inferior rate capability of only $41.4 \%$ and $70.7 \%$ of the original capacity of $131.5 \mathrm{mAh} \mathrm{g}^{-1}$ and $119.1 \mathrm{mAh} \mathrm{g}^{-}$ ${ }^{1}$, respectively, under the same conditions of increasing C-rate. The rate plots [Figure 4(c)] show that the high rate capability of the electrode containing the $0.06 \mathrm{LiNbO}_{3}-0.97 \mathrm{Li}_{1.08} \mathrm{Mn}_{1.92} \mathrm{O}_{4}$ composite materials is better than those of the electrodes containing the other $x \mathrm{LiNbO}_{3}-(1-$ $x / 2) \mathrm{Li}_{1.08} \mathrm{Mn}_{1.92} \mathrm{O}_{4}$ composite materials $(x=0,0.03$, and 0.1$)$, suggesting that the solid state electrolyte $\mathrm{LiNbO}_{3}$ coating layer plays an important role in the rate capability. Electrodes with partially $\mathrm{LiNbO}_{3}$ coated lithium-rich manganese oxide also show good rate capability, however, the rate capability is inferior when the $\mathrm{LiNbO}_{3}$ is in the form of clusters, not layers, due to excess $\mathrm{Nb}$ element $\left(x=0.1\right.$ for $\left.x \mathrm{LiNbO}_{3}-(1-x / 2) \mathrm{Li}_{1.08} \mathrm{Mn}_{1.92} \mathrm{O}_{4}\right)$. It should be noted that the rate capability of the $x \mathrm{LiNbO}_{3}-(1-x / 2) \mathrm{Li}_{1.08} \mathrm{Mn}_{1.92} \mathrm{O}_{4}$ composite materials $(x=0.03,0.06$, and 0.1$)$ is better than that of the pristine $\mathrm{Li}_{1.08} \mathrm{Mn}_{1.92} \mathrm{O}_{4}$.

The electrochemical delithiation/lithiation processes were also investigated via in situ SXRD. As can be seen from Figure 5 and Figure S6, the $0.06 \mathrm{LiNbO}_{3}-0.97 \mathrm{Li}_{1.08} \mathrm{Mn}_{1.92} \mathrm{O}_{4}$ composite material has undergone highly reversible changes in crystal structure at $0.5 \mathrm{C}$ and room temperature. During the charge process, the lattice constant of $\mathrm{Li}_{1.08} \mathrm{Mn}_{1.92} \mathrm{O}_{4}$ gradually decreases from $a=8.228 \AA$ (voltage $=3.22 \mathrm{~V}$, open circuit potential) to $a=8.066 \AA$ (Voltage $=$ 4.5 V), with the SXRD peaks corresponding to shifts in the peaks of $\mathrm{Li}_{1.08} \mathrm{Mn}_{1.92} \mathrm{O}_{4}$ to higher angles [Figure 5(b), (d), and (e)]. A similar phenomenon appears during the discharge process, in which the SXRD peaks are shifted backward from their initial position $(a=8.225 \AA$, voltage $=$ $3.2 \mathrm{~V}$ ). No new crystal structure is generated during the delithiation/lithiation processes. That is 
to say, there is no nucleation and growth of a second phase, so that the spinel structure avoids rearrangement and large volume changes. ${ }^{45-48}$ It should be pointed out that lithium shows preferred nucleation and growth orientation during the charge/discharge process [lithium (220) reflection, Fig 5(a)]. As can be seen from Figure 6, a non-equilibrium solid solution phase,
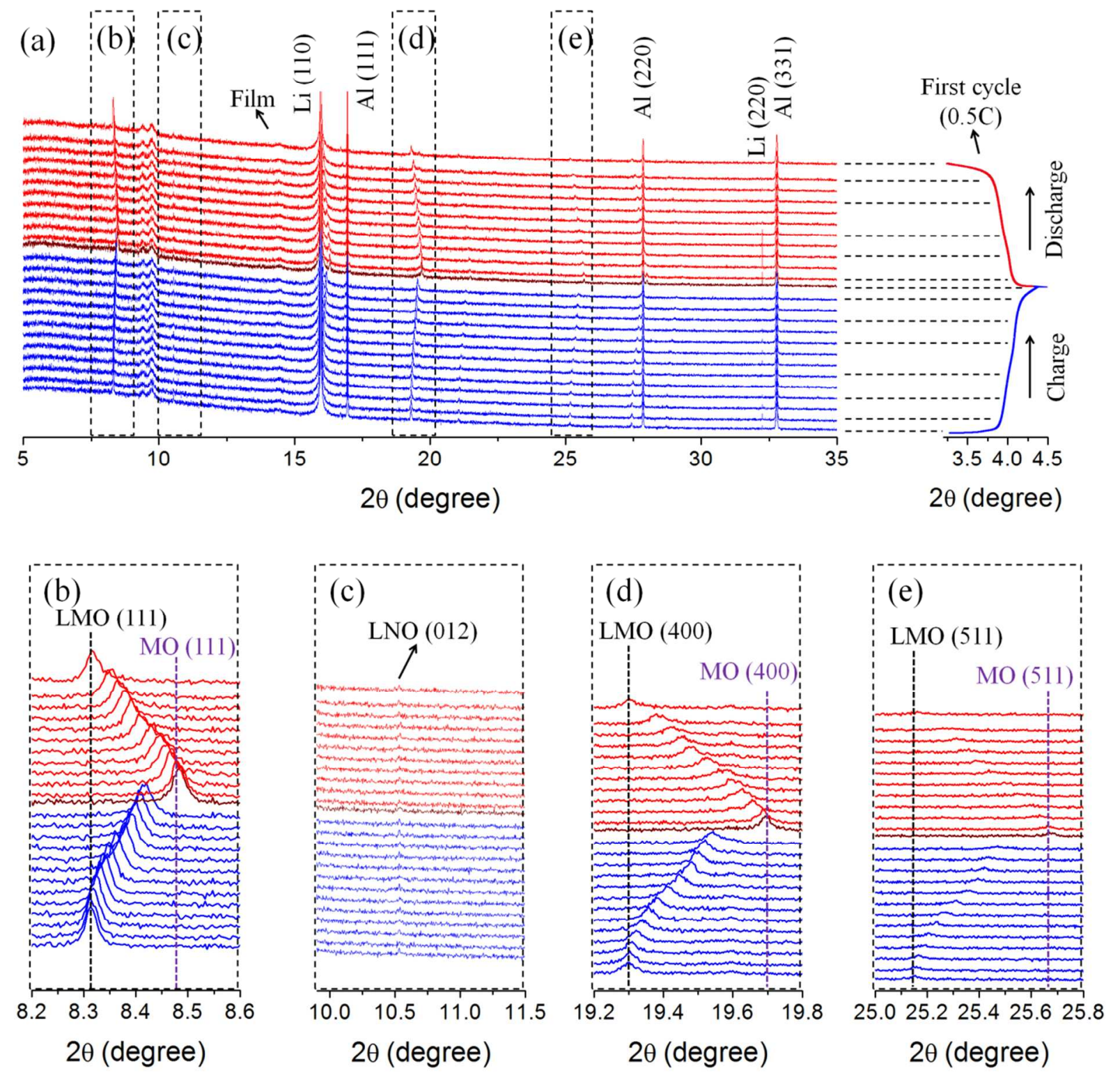

Figure 5. In situ SXRD patterns of $0.06 \mathrm{LiNbO}_{3}-0.97 \mathrm{Li}_{1.08} \mathrm{Mn}_{1.92} \mathrm{O}_{4}$ during the first cycle at $0.5 \mathrm{C}$.

(a) Selected individual diffraction patterns during the first cycle stacked against the 
charge/discharge curve. The main peaks of $\mathrm{Li}_{1.08} \mathrm{Mn}_{1.92} \mathrm{O}_{4}$ correspond to the (b) (111), (d) (400), and (e) (511) reflections. These regions are highlighted in the bottom columns, and peaks corresponding to the $\mathrm{Li}_{1.08} \mathrm{Mn}_{1.92} \mathrm{O}_{4}$ and $\lambda-\mathrm{MnO}_{2}\left(\mathrm{Li}_{0.04} \mathrm{Mn}_{0.96} \mathrm{O}_{2}\right)$ phases are marked by black dotted lines and purple dotted lines, respectively. For the $\mathrm{LiNbO}_{3}$ phase, the main peak that corresponds to the (012) reflection is also highlighted in the bottom columns (c). LMO: $\mathrm{Li}_{1.08} \mathrm{Mn}_{1.92} \mathrm{O}_{4} ; \mathrm{MO}: \mathrm{Li}_{0.04} \mathrm{Mn}_{0.96} \mathrm{O}_{2}\left(\lambda-\mathrm{MnO}_{2}\right)$; LNO: $\mathrm{LiNbO}_{3}$.

$\mathrm{Li}_{x+0.08} \mathrm{Mn}_{1.92} \mathrm{O}_{4}(0<\mathrm{x}<1)$, spans the entire composition between the two thermodynamic phases, $\mathrm{Li}_{1.08} \mathrm{Mn}_{1.92} \mathrm{O}_{4}$ and $\mathrm{Li}_{0.04} \mathrm{Mn}_{0.96} \mathrm{O}_{2}\left(\lambda-\mathrm{MnO}_{2}\right)$. An analogous phenomenon has also been reported in $\mathrm{Li}_{1.06} \mathrm{Mn}_{2} \mathrm{O}_{4}$ and $\mathrm{LiFePO}_{4}$ cathode materials for LIBs. ${ }^{33,}{ }^{45}$ From Figure 5(c), we can see that the SSE coating layer of $\mathrm{LiNbO}_{3}$ shows a weak (012) reflection. No peak shifts of $\mathrm{LiNbO}_{3}$ appear throughout the charge/discharge process. The dual structure of the cathode material, a stable $\mathrm{LiNbO}_{3}$ structure (Figure S7) and a non-equilibrium solid solution phase $\left[\mathrm{Li}_{x+0.08} \mathrm{Mn}_{1.92} \mathrm{O}_{4}(0<\mathrm{x}<1)\right]$, effectively prevents the soluble $\mathrm{Mn}^{2+}$ from being generated and diffusing to the OLE, and avoids the splitting up of $\mathrm{Li}_{1.08} \mathrm{Mn}_{1.92} \mathrm{O}_{4}$ particles caused by the slight crystal volume change. Although SSE presents a low Li-ion transfer rate in all solid state batteries, there is no obvious evidence that the thin $\mathrm{LiNbO}_{3} \mathrm{SSE}$ coating layer affects the Li-ion transfer rate from the in situ SXRD results. Therefore, the low-energy non-equilibrium solid solution phase $\left[\mathrm{Li}_{x+0.08} \mathrm{Mn}_{1.92} \mathrm{O}_{4}(0<\mathrm{x}<1)\right]$ and the stable $\mathrm{SSE}$ coating layer of $\mathrm{LiNbO}_{3}$ can increase the high-rate capability and cycling stability. 


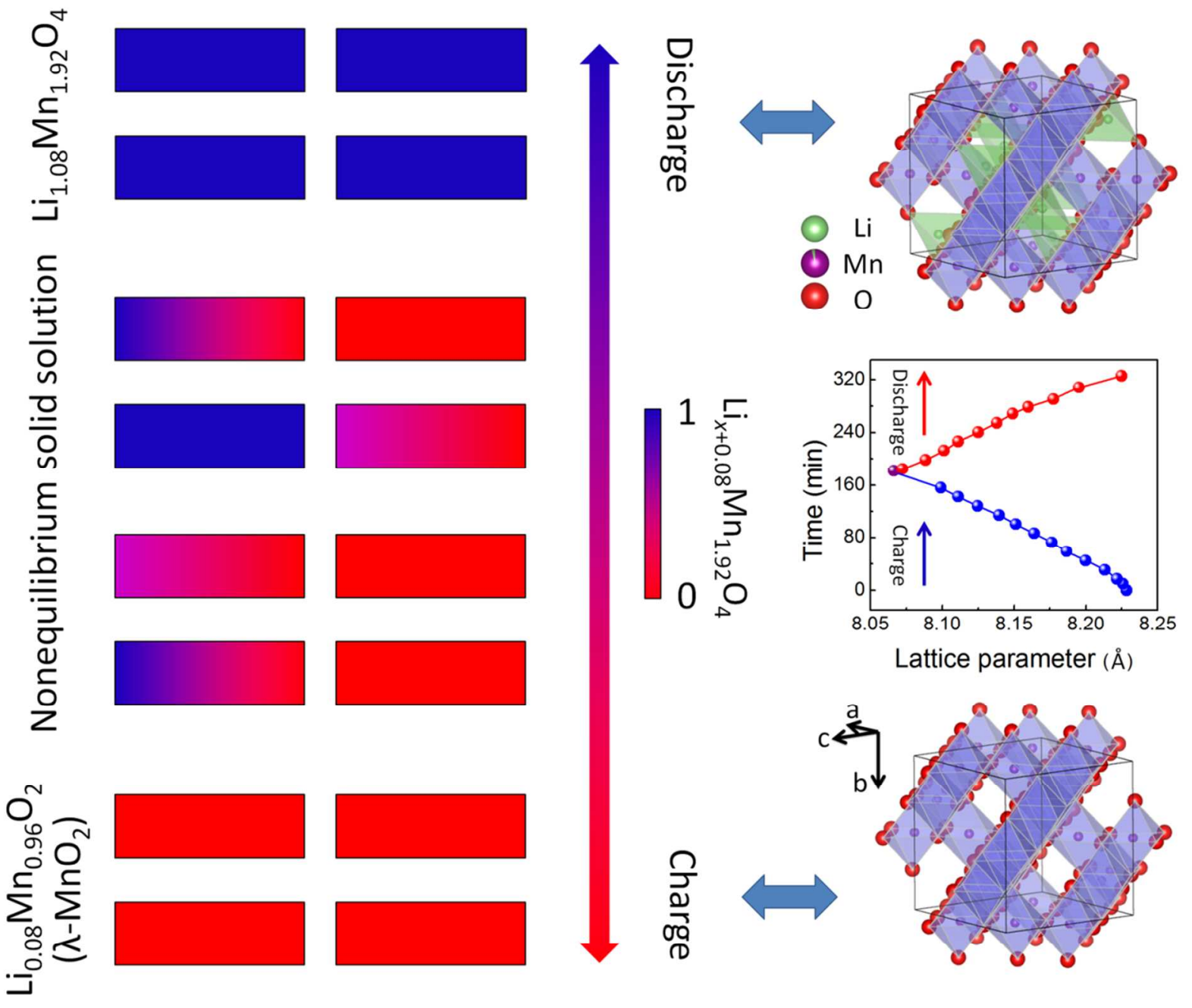

Figure 6. Phase transformation from $\mathrm{Li}_{1.08} \mathrm{Mn}_{1.92} \mathrm{O}_{4}$ (blue) to $\mathrm{Li}_{0.04} \mathrm{Mn}_{0.96} \mathrm{O}_{2}\left(\lambda-\mathrm{MnO}_{2}\right.$, red) and the structural relations between $\mathrm{Li}_{1.08} \mathrm{Mn}_{1.92} \mathrm{O}_{4}$ and $\mathrm{Li}_{0.04} \mathrm{Mn}_{0.96} \mathrm{O}_{2} \quad\left(\lambda-\mathrm{MnO}_{2}\right)$ with the corresponding lattice parameter changes. The lattice parameter changes with charge/discharge time correspond to the selected individual diffraction patterns [Figure 5(b)]. The delithiation/lithiation proceeds at $0.5 \mathrm{C}$ via the formation of a non-equilibrium solid solution phase, $\mathrm{Li}_{x+0.08} \mathrm{Mn}_{1.92} \mathrm{O}_{4}$ (intermediate pink color). When the charge/discharge process is finished, the particles have reached their equilibrium configuration corresponding to the $\mathrm{Li}_{0.04} \mathrm{Mn}_{0.96} \mathrm{O}_{2}(\lambda$ $\mathrm{MnO}_{2}$ ) and $\mathrm{Li}_{1.08} \mathrm{Mn}_{1.92} \mathrm{O}_{4}$ structures. 

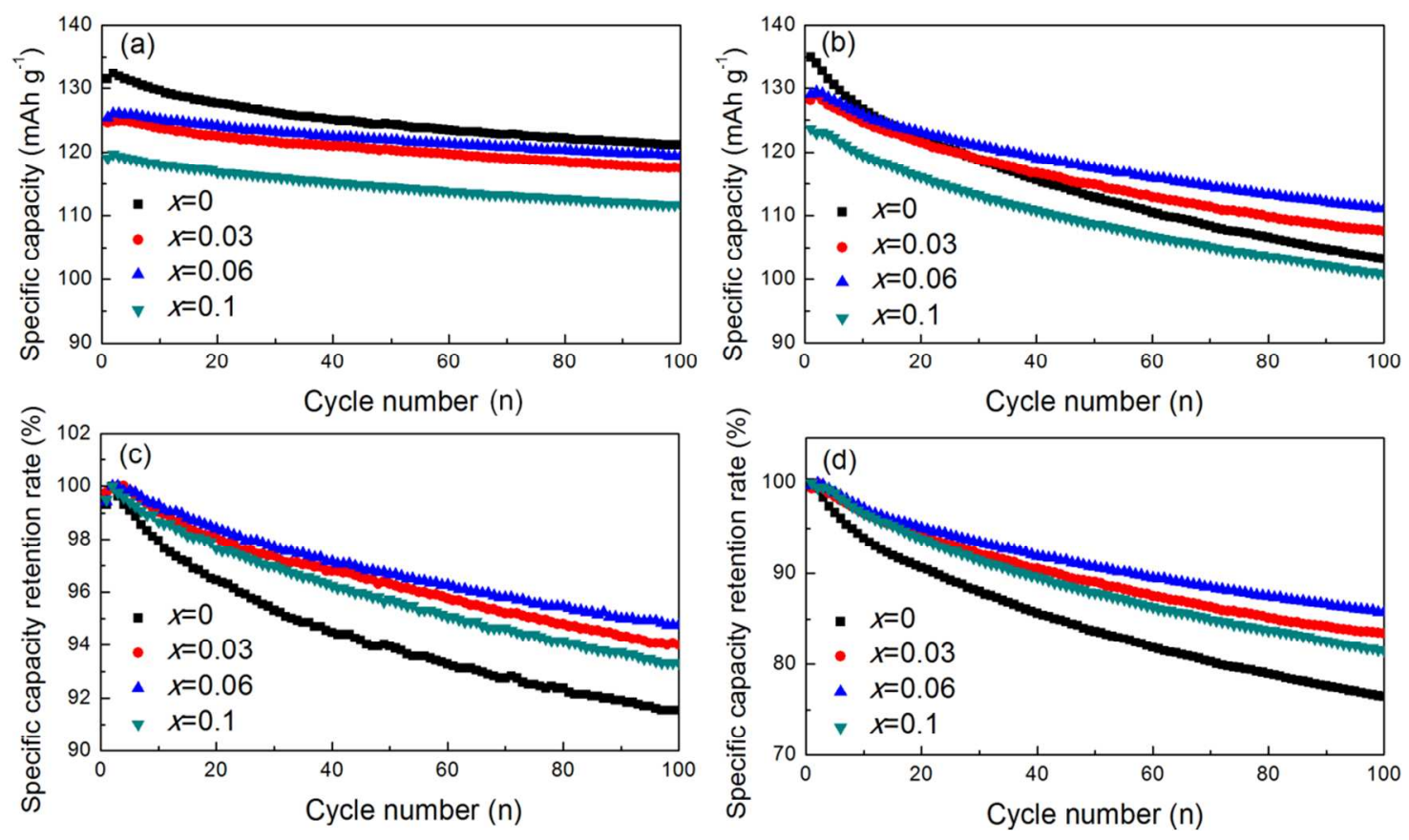

Figure 7. Cycling performance $(\mathrm{a}, \mathrm{b})$ and capacity retention rate $(\mathrm{c}, \mathrm{d})$ for $x \mathrm{LiNbO}_{3}-(1-$ $x / 2) \mathrm{Li}_{1.08} \mathrm{Mn}_{1.92} \mathrm{O}_{4}$ electrodes $(x=0,0.03,0.06$, and 0.1$)$ at current density of $0.5 \mathrm{C}$ with a potential window of 4.5-3.2 V: (a) and (c) at $25{ }^{\circ} \mathrm{C}$, (b) and (d) at $55{ }^{\circ} \mathrm{C}$. The cycling retention rate is expressed as a relative specific discharge capacity compared to that obtained from the first cycle.

To investigate the cycling stability, the variation in the discharge capacity of the electrodes over 100 cycles is shown in Figure 7, where there is a comparison between $\mathrm{Li}_{1.08} \mathrm{Mn}_{1.92} \mathrm{O}_{4}$ samples containing different amounts of $\mathrm{SSE}-\mathrm{LiNbO}_{3}$. The initial discharge specific capacities, at a rate of $0.5 \mathrm{C}$, are $131.9 \mathrm{mAh} \mathrm{g}^{-1}, 123.8 \mathrm{mAh} \mathrm{g}^{-1}, 124.7 \mathrm{mAh} \mathrm{g}^{-1}$, and 119.7 $\mathrm{mAh} \mathrm{g}^{-1}$ for $x \mathrm{LiNbO}_{3}-(1-x / 2) \mathrm{Li}_{1.08} \mathrm{Mn}_{1.92} \mathrm{O}_{4}$ electrodes with $x=0,0.03,0.06$, and 0.1 , respectively [Figure 7(a)]. The retained discharge capacity was 91.4\%, 94.1\%, 95.7\%, and 93.1\%, respectively, after 100 cycles, in comparison with the initial capacity (corresponding discharge capacity: $120.6 \mathrm{mAh} \mathrm{g}^{-1}, 116.5 \mathrm{mAh} \mathrm{g}^{-1}, 119.4 \mathrm{mAh} \mathrm{g}^{-1}$, and $111.5 \mathrm{mAh} \mathrm{g}^{-1}$ ) [Figure 
7(c)]. The behavior of $x \mathrm{LiNbO}_{3}-(1-x / 2) \mathrm{Li}_{1.08} \mathrm{Mn}_{1.92} \mathrm{O}_{4}(x=0,0.03,0.06$, and 0.1$)$ at high temperature $\left(55^{\circ} \mathrm{C}\right)$ has also been investigated and is shown in Figure $7(\mathrm{~b})$ and (d). The pristine $\mathrm{Li}_{1.08} \mathrm{Mn}_{1.92} \mathrm{O}_{4}$ shows a higher initial capacity than that of the same electrode at $25{ }^{\circ} \mathrm{C}$ and there was a $23.7 \%$ capacity loss after 100 cycles from $135 \mathrm{mAh} \mathrm{g}^{-1}$ to $103 \mathrm{mAh} \mathrm{g}^{-1}$. In contrast, $0.06 \mathrm{LiNbO}_{3}-0.97 \mathrm{Li}_{1.08} \mathrm{Mn}_{1.92} \mathrm{O}_{4}$ exhibits much greater cycling stability than the pristine compound, with only $14.3 \%$ capacity loss after 100 cycles from $139.1 \mathrm{mAh} \mathrm{g}^{-1}$ to $111.0 \mathrm{mAh} \mathrm{g}^{-1}$. All of the samples with the $\mathrm{LiNbO}_{3}$ coating layer show stable cycling performance at $55{ }^{\circ} \mathrm{C}$, although the capacity exhibits more fading compared with the pristine $\mathrm{Li}_{1.08} \mathrm{Mn}_{1.92} \mathrm{O}_{4}$ when the mol ratio of $\mathrm{LiNbO}_{3}$ is 0.1 in the $x \mathrm{LiNbO}_{3}-(1-x / 2) \mathrm{Li}_{1.08} \mathrm{Mn}_{1.92} \mathrm{O}_{4}$ composite materials. In accordance with those cycling stability results, a thin and uniform $\mathrm{LiNbO}_{3}$-coating layer on the surface of $\mathrm{Li}_{1.08} \mathrm{Mn}_{1.92} \mathrm{O}_{4}$ increases the high rate capability, prevents capacity fading and decrease the capacity loss caused by the weight percentage of $\mathrm{LiNbO}_{3}$, especially at high temperature. The cycling performance of $0.06 \mathrm{LiNbO}_{3}-0.97 \mathrm{Li}_{1.08} \mathrm{Mn}_{1.92} \mathrm{O}_{4}$ at $25{ }^{\circ} \mathrm{C}$ and $55{ }^{\circ} \mathrm{C}$ is not only in sharp contrast to that of the pristine $\mathrm{Li}_{1.08} \mathrm{Mn}_{1.92} \mathrm{O}_{4}$, but also compares favorably with the widely reported results for cycling stability of $\mathrm{Li}_{1+x} \mathrm{Mn}_{2-x} \mathrm{O}_{4}$ with or without a coating layer (Table 3).

Table 3. Cycling and rate performance of $\mathrm{Li}_{1+x} \mathrm{Mn}_{2-x} \mathrm{O}_{4}$ spinel cathodes in the literature ${ }^{a}$.

\begin{tabular}{|c|c|c|c|c|c|c|c|}
\hline \multirow[b]{2}{*}{ Composition } & \multicolumn{2}{|c|}{ Initial capacity } & \multicolumn{2}{|c|}{ Capacity retention ${ }^{\mathrm{b}}$} & \multicolumn{2}{|c|}{ Rate capability ${ }^{c}$} & \multirow[b]{2}{*}{ Reference } \\
\hline & $(\mathrm{mAh}$ & & (\%) a & & (C) a & & \\
\hline $0.06 \mathrm{LiNbO}_{3}-0.97 \mathrm{Li}_{1.08} \mathrm{Mn}_{1.92} \mathrm{O}_{4}$ & 125 & 0.5 & 96 & 100 & 50 & 88 & Current work \\
\hline $\mathrm{LiMn}_{2} \mathrm{O}_{4}$ & $\sim 135$ & 0.33 & $\sim 92$ & 50 & 1 & 1 & 41 \\
\hline $\mathrm{LiMn}_{2} \mathrm{O}_{4}$ & $\sim 115$ & 10 & $\sim 91$ & 400 & 100 & 81 & 49 \\
\hline $\mathrm{LiMn}_{2} \mathrm{O}_{4}$ & 105 & 10 & I & I & 30 & 52 & 50 \\
\hline $\mathrm{Li}_{1.03} \mathrm{Mn}_{1.97} \mathrm{O}_{4}$ & 127 & 1 & 91 & 100 & 10 & 84 & 42 \\
\hline $\mathrm{Li}_{1.05} \mathrm{Mn}_{2} \mathrm{O}_{4}$ & $\sim 120$ & 10 & $\sim 75$ & 200 & I & I & 39 \\
\hline $\mathrm{Li}_{1.05} \mathrm{Mn}_{1.95} \mathrm{O}_{4}$ & 116 & 0.2 & $\sim 91$ & 150 & I & 1 & 51 \\
\hline $\mathrm{Li}_{1.08} \mathrm{Mn}_{2} \mathrm{O}_{4}$ & 123 & 0.2 & 84 & 25 & I & 1 & 52 \\
\hline $\mathrm{Li}_{1.05} \mathrm{Mn}_{2} \mathrm{O}_{4.1}$ & 119 & 0.33 & 92 & 50 & 1 & 1 & 34 \\
\hline
\end{tabular}




\begin{tabular}{lccccccc}
\hline $\mathrm{LiMn}_{2} \mathrm{O}_{4}-6.3 w t \% A g$ & 123 & 1 & 94 & 50 & 10 & 94 & 53 \\
$\mathrm{Li}_{1.08} \mathrm{Mn}_{2} \mathrm{O}_{4}-0.1 \mathrm{wt} \% \mathrm{LBO}$ & 122 & 0.2 & 87 & 25 & $/$ & $/$ & 52 \\
$\mathrm{LiMn}_{2} \mathrm{O}_{4}-7 \mathrm{~mol} \% \mathrm{LiCoO}$ & & 0.2 & 92 & 100 & $/$ & $/$ & 54 \\
\hline
\end{tabular}

${ }^{a}$ Comparisons may only be approximate due to the diversity of cell assembly techniques in different laboratories. ${ }^{b}$ Capacity after 100 cycles compared with the initial capacity at room temperature and the corresponding discharge current density. ${ }^{c}$ High rate current density and capacity retention compared with the capacity at around $0.5 \mathrm{C}$ and room temperature.

To further investigate the influence of the SSE coating layer on the LIBs when combined with OLE, the electrochemical kinetics for the $x \mathrm{LiNbO}_{3}-(1-x / 2) \mathrm{Li}_{1.08} \mathrm{Mn}_{1.92} \mathrm{O}_{4}(x=0,0.03,0.06$, and 0.1 ) electrodes was examined by electrochemical impedance spectroscopy (EIS). Figure S8 shows the Nyquist plots at discharge potential of $4.0 \mathrm{~V}$ vs. $\mathrm{Li} / \mathrm{Li}^{+}$at different temperatures after 5 cycles. All the impedance curves show two partially overlapping semicircles in the high to medium frequency region, which could be assigned to the film resistance $\left(R_{f}\right)$, associated with the solid electrolyte interphase (SEI), and the charge transfer resistance $\left(R_{c t}\right)$, respectively. A line inclined at approximately $45^{\circ}$ reflects the Warburg impedance $(W)$, which is associated with the lithium-ion diffusion in the $\mathrm{Li}_{1.08} \mathrm{Mn}_{1.92} \mathrm{O}_{4}$ compound. The high-frequency intercept of the semicircle reflects the uncompensated resistance $\left(R_{l}\right)$, which includes the particle-particle contact resistance, the electrolyte resistance, and the resistance between the cathode materials and the current collector. ${ }^{55}$ The $R_{f}, R_{c t}$, and $R_{l}$ values for the $x \mathrm{LiNbO}_{3}-(1-x / 2) \mathrm{Li}_{1.08} \mathrm{Mn}_{1.92} \mathrm{O}_{4}(x=0,0.03$, 0.06, and 0.1) electrodes were obtained using the equivalent circuit shown in the inset of Figure $\mathrm{S} 8$ (a) (calculated by Zview and shown in Table $\mathrm{S} 6$ ). The $R_{l}$ of the $\mathrm{LiNbO}_{3}$-coated $\mathrm{Li}_{1.08} \mathrm{Mn}_{1.92} \mathrm{O}_{4}$ electrodes is slightly higher than that of the pristine $\mathrm{Li}_{1.08} \mathrm{Mn}_{1.92} \mathrm{O}_{4}$ electrode, whereas the $R_{f}$ is apparently decreased after coating with $\mathrm{LiNbO}_{3}$. This indicates that the $\mathrm{LiNbO}_{3}$ coating layer effectively hinders SEI formation. The lithium diffusion coefficients and apparent activation energies of the $x \mathrm{LiNbO}_{3}-(1-x / 2) \mathrm{Li}_{1.08} \mathrm{Mn}_{1.92} \mathrm{O}_{4}(x=0,0.03,0.06$, and 0.1$)$ electrodes were 
calculated from EIS results using a previously reported method (The details show in Supporting Information). ${ }^{56,57}$

The lithium diffusion coefficients are calculated to be $(1.1,9.1,11.3$, and 6.3$) \times 10^{-12} \mathrm{~cm}^{2}$ $\mathrm{s}^{-1}$ for the $x \mathrm{LiNbO}_{3}-(1-x / 2) \mathrm{Li}_{1.08} \mathrm{Mn}_{1.92} \mathrm{O}_{4}(x=0,0.03,0.06$, and 0.1$)$ electrodes, respectively, at $24{ }^{\circ} \mathrm{C}$. The $0.6 \mathrm{LiNbO}_{3}-0.97 \mathrm{Li}_{1.08} \mathrm{Mn}_{1.92} \mathrm{O}_{4}$ composite material with a thin and uniform coating layer exhibits the highest lithium diffusion coefficient. The high lithium diffusion coefficient is also owing to the high ionic conductivity of the $\mathrm{SSE}_{-} \mathrm{LiNbO}_{3}$ coating layer. During the sintering process at high temperature, the primary particles (around $500 \mathrm{~nm}$ in size) were merged into secondary particles (about $1 \mu \mathrm{m}$ ), as shown in Figure 3 and Figure $\mathrm{S} 3$. The portion of $\mathrm{LiNbO}_{3}$ that is located in the interior of the secondary particles (due to the coating on the primary particles) effectively improves the lithium diffusion coefficient. The lithium diffusion coefficient increases with increasing of $\mathrm{LiNbO}_{3}$ uniformity on the surface of the $\mathrm{Li}_{1.08} \mathrm{Mn}_{1.92} \mathrm{O}_{4}$ crystal. When the primary $\mathrm{Li}_{1.08} \mathrm{Mn}_{1.92} \mathrm{O}_{4}$ particles have a thin and uniform coating layer, there will be a three-dimensional (3D) $\mathrm{LiNbO}_{3}$ net structure. This $3 \mathrm{D} \mathrm{LiNbO}_{3}$ net structure effectively decreases the lithium diffusion distance and increases the lithium diffusion coefficient. The lithium diffusion coefficient was also calculated at different temperatures [Figure 8(a)]. The lithium diffusion coefficient increases as the temperature increases.

The apparent activation energies $\left(E_{\mathrm{a}}\right)$ of the $x \mathrm{LiNbO}_{3}-(1-x / 2) \mathrm{Li}_{1.08} \mathrm{Mn}_{1.92} \mathrm{O}_{4}(x=0,0.03$, 0.06, and 0.1) electrodes are shown in Figure 8(d). The $0.6 \mathrm{LiNbO}_{3}-0.97 \mathrm{Li}_{1.08} \mathrm{Mn}_{1.92} \mathrm{O}_{4}$ composite material with a thin and uniform coating layer exhibits the lowest $E_{\mathrm{a}}(36.9 \mathrm{~kJ}$, error within $1.5 \%)$. The diffusion apparent activation energy $\left(E_{\mathrm{aD}}\right)$ can also be calculated from the plots of $\lg D$ vs. 1/T using the equation: $E_{\mathrm{aD}}=-R k \ln 10$, where $k$ is the slope of the fitting line in Fig. 8(c). The diffusion apparent activation energy is shown in Figure $8(\mathrm{~d})$, and the trend in the values as the 
amount of $\mathrm{Nb}$ element increases is similar to that for $E_{\mathrm{a}}$ (based on the Arrhenius equation). The lowest $E_{\mathrm{aD}}(75.8 \mathrm{~kJ}$, error within $1 \%)$ appears for the $0.6 \mathrm{LiNbO}_{3}-0.97 \mathrm{Li}_{1.08} \mathrm{Mn}_{1.92} \mathrm{O}_{4}$ composite material with a thin and uniform coating layer, corresponding to the lithium diffusion coefficient results.
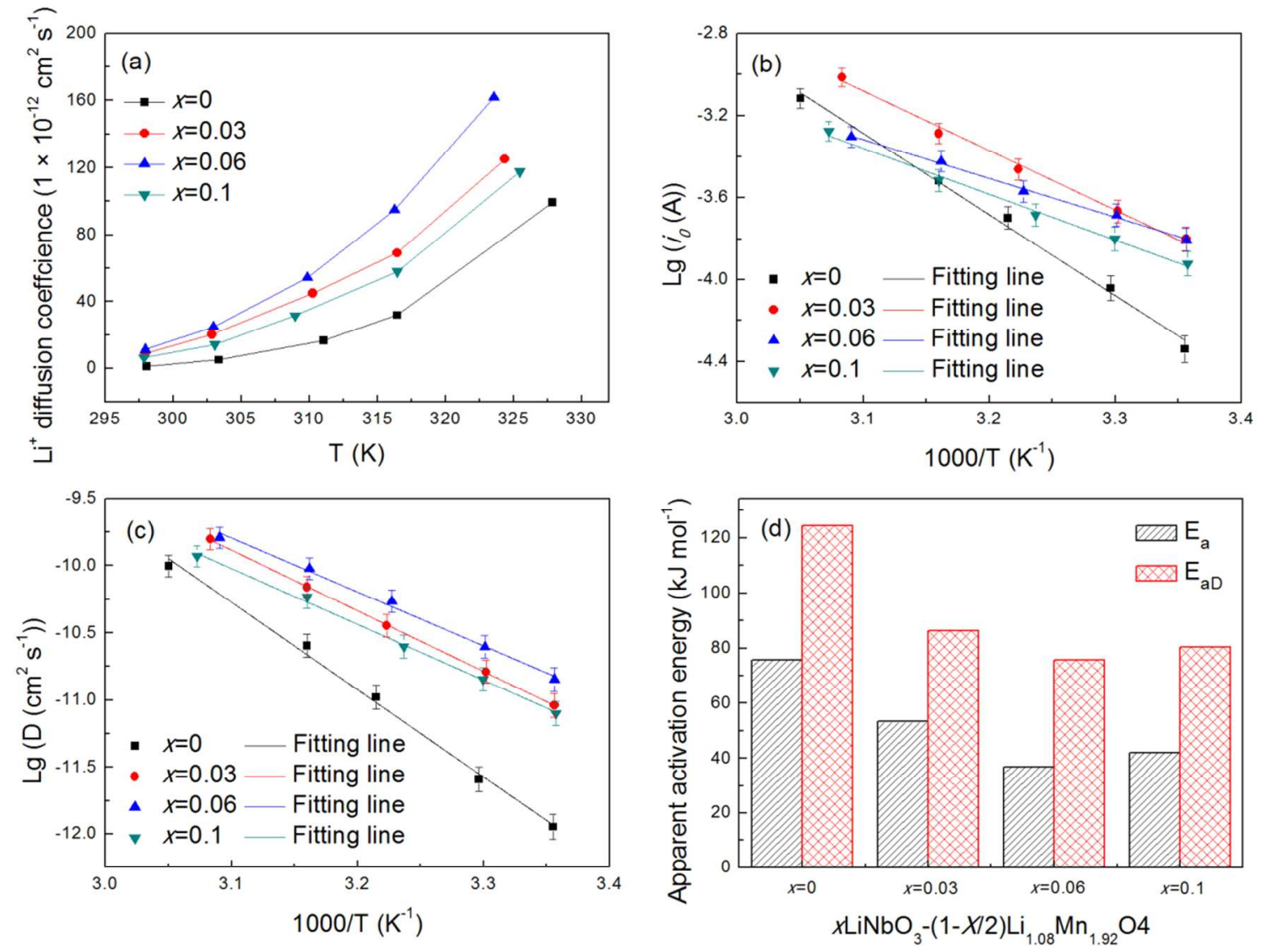

Figure 8. Electrochemical kinetics for $x \mathrm{LiNbO}_{3}-(1-x / 2) \mathrm{Li}_{1.08} \mathrm{Mn}_{1.92} \mathrm{O}_{4}(x=0,0.03,0.06$, and 0.1$)$ electrodes at a discharge potential of $4.0 \mathrm{~V}$ vs. $\mathrm{Li} / \mathrm{Li}^{+}$: (a) Arrhenius plots of $\lg i_{0}$ versus $1 / T$. The lines are the linear fitting results; (b) lithium diffusion coefficients at different temperatures; (c) $\operatorname{Lg} D$ versus $1 / T$ plots during lithium insertion, with the solid lines indicating the linear fitting results; (d) comparison of $E_{\mathrm{a}}$ and $E_{\mathrm{aD}}$ (activation energy based on the Arrhenius equation and on the lithium diffusion coefficient, respectively). 
The excellent electrochemical stability of the $0.06 \mathrm{LiNbO}_{3}-0.97 \mathrm{Li}_{1.08} \mathrm{Mn}_{1.92} \mathrm{O}_{4}$ composite material is also confirmed by the images of electrodes, which were collected after 100 cycles at $0.5 \mathrm{C}$ and $25{ }^{\circ} \mathrm{C}$ (Figure S10). As can be seen from the optical digital photographs (Figure S10: the right sides of the FESEM images), the morphology of the $0.06 \mathrm{LiNbO}_{3}-0.97 \mathrm{Li}_{1.08} \mathrm{Mn}_{1.92} \mathrm{O}_{4}$ cathode electrode after 100 charge-discharge cycles is still smooth and flat, and the counter anode (lithium foil) and separator do not show manganese deposition from cathode dissolution, whereas the pristine $\mathrm{Li}_{1.08} \mathrm{Mn}_{1.92} \mathrm{O}_{4}$ cathode electrode after 100 charge-discharge cycles shows a rough surface, and the surfaces of the counter anode (lithium foil) and separator exhibit an obvious black slurry from cathode manganese dissolution. Figure S10 (a) and (b) presents the respective FESEM images of the $0.06 \mathrm{LiNbO}_{3}-0.97 \mathrm{Li}_{1.08} \mathrm{Mn}_{1.92} \mathrm{O}_{4}$ and pristine $\mathrm{Li}_{1.08} \mathrm{Mn}_{1.92} \mathrm{O}_{4}$ cathodes after 100 cycles at $0.5 \mathrm{C}$ and $25{ }^{\circ} \mathrm{C}$. It can be found by comparing the two cathodes that the pristine $\mathrm{Li}_{1.08} \mathrm{Mn}_{1.92} \mathrm{O}_{4}$ particles are separated from each other and shrunken within the secondary particles, but this did not occur in the $\mathrm{LiNbO}_{3}$-coated cathode. Due to the sintering at high temperature, the primary particles (around $500 \mathrm{~nm}$ in size) were merged into secondary particles (about $1 \mu \mathrm{m}$ ), as shown in Figure S3. Similar to what was previously reported, the formation of $\mathrm{Mn}^{3+}$ leads to $\mathrm{Mn}$ dissolution, and Jahn-Teller crystallographic distortion causes the primary particles of $\mathrm{Li}_{1.08} \mathrm{Mn}_{1.92} \mathrm{O}_{4}$ to separate and shrink. ${ }^{58,59}$ Therefore, the SSE- $\mathrm{LiNbO}_{3}$ coating layer prevents the soluble $\mathrm{Mn}^{2+}$ from passing into the electrolyte and allows the $\mathrm{Li}^{+}$ions free transportation among the cathode, OLE, and anode, while there are no reports that conventional coating layers can decrease the lithium ionic conduction and/or charge transfer reaction between the electrode and electrolyte. ${ }^{21-29}$

\section{Conclusion}


SSE-LiNbO 3 coating layers on manganese spinel cathode were successfully introduced into LIBs with an organic liquid electrolyte system using a facile solid-state reaction method. The $\mathrm{Li}_{1.08} \mathrm{Mn}_{1.92} \mathrm{O}_{4}$ sample with a thin and uniform coating layer exhibited higher cycling stability, higher rate capability, and better high temperature cycling performance than the pristine $\mathrm{Li}_{1.08} \mathrm{Mn}_{1.92} \mathrm{O}_{4}$. The SSE-LiNbO 3 coating layer effectively prevented $\mathrm{Mn}$ dissolution, and the $\mathrm{Li}_{1.08} \mathrm{Mn}_{1.92} \mathrm{O}_{4}$ samples with $\mathrm{LiNbO}_{3}$ coating layers showed much lower charge transfer resistance, lower apparent activation energy, and lower apparent diffusion activation energy than the pristine $\mathrm{Li}_{1.08} \mathrm{Mn}_{1.92} \mathrm{O}_{4}$ sample, due to their high ionic conductivity. The successful combination of a SSE coating layer with OLE in LIBs provides a clear direction for designing next-generation large-scale LIBs.

\section{Acknowledgements}

Financial support was provided by an Australian Research Council (ARC) Discovery Project (DP100103909). Zhijia Zhang is grateful to the China Scholarship Council (CSC) for scholarship support. Zhijia Zhang is grateful to the COMPANHIA BRASILEIRA DE METALURGIA E MINERAÇÃO (CBMM) for niobium oxide support. This research used equipment that was funded by Australian Research Council Grant LE0237478 and is located at the UOW Electron Microscopy Centre. Technical assistance on the TEM by Dr. Gilberto Casillas-Garcia is highly appreciated. Part of the experiments was performed at the Powder Diffraction Beamline at the Australian Synchrotron. Many thanks are owed to Dr. Tania Silver for critical reading of the manuscript.

\section{ASSOCIATED CONTENT}

\section{Supporting Information}


XRD patterns, SXRD patterns with refinement results, corresponding results for FESEM, TEM, $\mathrm{CV}$, and EIS with structural information for $x \mathrm{LiNbO}_{3}-(1-x / 2) \mathrm{Li}_{1.08} \mathrm{Mn}_{1.92} \mathrm{O}_{4}(x=0,0.03,0.06$, and 0.1 ). FESEM images of $0.06 \mathrm{LiNbO}_{3}-0.97 \mathrm{Li}_{1.08} \mathrm{Mn}_{1.92} \mathrm{O}_{4}$ electrode before and after cycling. This material is available free of charge via the Internet at http://pubs.acs.org.

\section{AUTHOR INFORMATION}

\section{Corresponding Author}

Jia-Zhao Wang: jiazhao@uow.edu.au

Address: Institute for Superconducting and Electronic Materials, University of Wollongong, Wollongong, NSW 2522, Australia

Telehone: +61 24298 1478; Fax: $\quad$ +61242215731

Hui-Jun Li: huijun@uow.edu.au

Address: Faculty of Engineering, University of Wollongong, Wollongong, NSW 2522, Australia Telehone: +612 4221 3491; Fax: +61242215474

\section{References}

(1) Zhang, R.; Zhang, Y.; Zhu, K.; Du, F.; Yang, X.; Wang, Y.; Bie, X.; Chen, G.; Wei, Y. Carbon and $\mathrm{RuO}_{2}$ Binary Surface Coating for the $\mathrm{Li}_{3} \mathrm{~V}_{2}\left(\mathrm{PO}_{4}\right)_{3}$ Cathode Material for Lithium-Ion Batteries. ACS Appl. Mater. Interfaces 2014, 6, 12523-12530.

(2) Etacheri, V.; Marom, R.; Elazari, R.; Salitra, G.; Aurbach, D. Challenges in the Development of Advanced Li-Ion Batteries: a Review. Energy Environ. Sci. 2011, 4, $3243-3262$. 
(3) Islam, M. S.; Fisher, C. A. J. Lithium and Sodium Battery Cathode Materials: Computational Insights into Voltage, Diffusion and Nanostructural Properties. Chem. Soc. Rev. 2014, 43, 185-204.

(4) Luo, D.; Li, G.; Fu, C.; Zheng, J.; Fan, J.; Li, Q.; Li, L. A New Spinel-Layered Li-Rich Microsphere as a High-Rate Cathode Material for Li-Ion Batteries. Adv. Energy Mater. 2014, DOI: 10.1002/aenm.201400062.

(5) Hao, X.; Lin, X.; Bartlett, B. M. Oxygen Vacancies Lead to Loss of Domain Order, Particle Fracture, and Rapid Capacity Fade in Lithium Manganospinel $\left(\mathrm{LiMn}_{2} \mathrm{O}_{4}\right)$ Batteries. ACS Appl. Mater. Interfaces 2014, 6, 10849-10857.

(6) Mishra, S.; Ceder, G. Structural Stability of Lithium Manganese Oxides. Phys. Rev. B 1999, 59, 6120.

(7) Xia, Y.; Zhou, Y.; Yoshio, M. Capacity Fading on Cycling of $4 \mathrm{~V} \mathrm{Li} / \mathrm{LiMn}_{2} \mathrm{O}_{4} \mathrm{Cell}_{\text {s. }} J$. Electrochem. Soc. 1997, 144, 2593-2600.

(8) Lee, M. J.; Lee, S.; Oh, P.; Kim, Y.; Cho, J. High Performance $\mathrm{LiMn}_{2} \mathrm{O}_{4}$ Cathode Materials Grown with Epitaxial Layered Nanostructure for Li-Ion Batteries. Nano Lett. 2014, 14, 993-999.

(9) Nazri, G. A.; Pistoia, G. Lithium Batteries: Science and Technology, Springer, New York 2004; Chapter 1, pp. 25-30.

(10) Park, O. K.; Cho, Y.; Lee, S.; Yoo, H. C.; Song, H. K.; Cho, J. Who Will Drive Electric Vehicles, Olivine or Spinel? Energy Environ. Sci. 2011, 4, 1621-1633.

(11) Aurbach, D.; Markovsky, B.; Salitra, G.; Markevich, E.; Talyossef, Y.; Koltypin, M.; Nazar, L.; Ellis, B.; Kovacheva, D. Review on Electrode-Electrolyte Solution 
Interactions, Related to Cathode Materials for Li-Ion Batteries. J. Power Sources 2007, $165,491-499$.

(12) Zhang, S. S. A Review on Electrolyte Additives for Lithium-Ion Batteries. J. Power Sources 2006, 162, 1379-1394.

(13) $\mathrm{Xu}, \mathrm{K}$. Nonaqueous Liquid Electrolytes for Lithium-Based Rechargeable Batteries. Chem. Rev. 2004, 104, 4303-4417.

(14) Oudenhoven, J. F.; Baggetto, L.; Notten, P. H. All-Solid-State Lithium-Ion Microbatteries: A Review of Various Three-Dimensional Concepts. Adv. Energy Mater. 2011, $1,10-33$.

(15) Aubrey, M.; Ameloot, R.; Wiers, B. M.; Long, J. R. Metal-Organic Frameworks as Solid Magnesium Electrolytes. Energy Environ. Sci. 2014, 7, 667-671.

(16) Stephan, A. M. Review on Gel Polymer Electrolytes for Lithium Batteries. Eur. Polym. J. 2006, 42, 21-42.

(17) Song, J.; Wang, Y.; Wan, C. Review of Gel-type Polymer Electrolytes for Lithium-Ion Batteries. J. Power Sources 1999, 77, 183-197.

(18) Ohta, N.; Takada, K.; Zhang, L.; Ma, R.; Osada, M.; Sasaki, T. Enhancement of the High-Rate Capability of Solid-State Lithium Batteries by Nanoscale Interfacial Modification. Adv. Mater. 2006, 18, 2226-2229.

(19) Tatsumisago, M.; Nagao, M.; Hayashi, A. Recent Development of Sulfide Solid Electrolytes and Interfacial Modification for All-Solid-State Rechargeable Lithium Batteries. J. Asian Ceram. Soc. 2013, 1, 17-25. 
(20) Haruyama, J.; Sodeyama, K.; Han, L.; Takada, K.; Tateyama, Y. Space-Charge Layer Effect at Interface between Oxide Cathode and Sulfide Electrolyte in All-Solid-State Lithium-Ion Battery. Chem. Mater. 2014, 26, 4248-4225.

(21) Gnanaraj, J.; Pol, V.; Gedanken, A.; Aurbach, D. Improving the High-Temperature Performance of $\mathrm{LiMn}_{2} \mathrm{O}_{4}$ Spinel Electrodes by Coating the Active Mass with $\mathrm{MgO}$ Via a Sonochemical Method. Electrochem. Commun. 2003, 5, 940-945.

(22) Myung, S. T.; Izumi, K.; Komaba, S.; Sun, Y. K.; Yashiro, H.; Kumagai, N. Role of Alumina Coating on Li-Ni-Co-Mn-O Particles as Positive Electrode Material for Lithium-Ion Batteries. Chem. Mater. 2005, 17, 3695-3704.

(23) Fan, Y.; Wang, J.; Tang, Z.; He, W.; Zhang J. Effects of the Nanostructured SiO2 Coating on the Performance of $\mathrm{LiNi}_{0.5} \mathrm{Mn}_{1.5} \mathrm{O}_{4}$ Cathode Materials for High-Voltage LiIon Batteries Electrochim. Acta 2007, 52, 3870-3875.

(24) Hu, S. K.; Cheng, G. H.; Cheng, M. Y.; Hwang, B. J.; Santhanam, R. Cycle Life Improvement of $\mathrm{ZrO}_{2}$-coated Spherical $\mathrm{LiNi}_{1 / 3} \mathrm{Co}_{1 / 3} \mathrm{Mn}_{1 / 3} \mathrm{O}_{2}$ Cathode Material for Lithium Ion Batteries. J. Power Sources 2009, 188, 564-569.

(25) Zhang, Z. J.; Wang, J. Z.; Chou, S. L.; Liu, H. K.; Ozawa, K.; Li, H. J. PolypyrroleCoated $\alpha-\mathrm{LiFeO}_{2}$ Nanocomposite with Enhanced Electrochemical Properties for Lithiumion Batteries. Electrochim. Acta 2013, 108, 820-826.

(26) Gangopadhyay, R.; De, A. Conducting Polymer Nanocomposites: A Brief Overview. Chem. Mater. 2000, 12, 608-622.

(27) Ng, S. H.; Wang, J. Z.; Wexler, D.; Konstantinov, K.; Guo, Z. P.; Liu, H. K. Highly Reversible Lithium Storage in Spheroidal Carbon-Coated Silicon Nanocomposites as Anodes for Lithium-Ion Batteries. Angew. Chem., Int. Ed. 2006, 45, 6896-6899. 
(28) Shi, Y.; Chou, S. L.; Wang, J. Z.; Wexler, D.; Li, H. J.; Liu, H. K.; Wu, Y. Graphene Wrapped LiFePO4/C Composites as Cathode Materials for Li-Ion Batteries with Enhanced Rate Capability. J. Mater. Chem. 2012, 22, 16465-16470.

(29) Noh, H. K.; Park, H. S.; Jeong, H. Y.; Lee, S. U.; Song, H. K. Doubling the Capacity of Lithium Manganese Oxide Spinel by a Flexible Skinny Graphitic Layer. Angew. Chem., Int. Ed. 2014, 126, 5159-5163.

(30) Ma, Z.; Shao, G.; Fan, Y.; Wang, G.; Song, J.; Liu, T. Tunable Morphology Synthesis of $\mathrm{LiFePO}_{4}$ Nanoparticles as Cathode Materials for Lithium Ion Batteries. ACS Appl. Mater. Interfaces 2014, 6, 9236-9244.

(31) Glass, A.; Nassau, K.; Negran, T. Ionic Conductivity of Quenched Alkali Niobate and Tantalate Glasses. J. Appl. Phys. 1978, 49, 4808-4811.

(32) Ohta, N.; Takada, K.; Sakaguchi, I.; Zhang, L.; Ma, R.; Fukuda, K.; Osada, M.; Sasaki, T. LiNbO3-coated LiCoO2 as Cathode Material for All Solid-State Lithium Secondary Batteries. Electrochem. Commun. 2007, 9, 1486-1490.

Xia, Y.; Sakai, T.; Fujieda, T.; Yang, X.; Sun, X.; Ma, Z.; McBreen, J.; Yoshio, M. Correlating Capacity Fading and Structural Changes in $\mathrm{Li}_{1+y} \mathrm{Mn}_{2-\mathrm{y}} \mathrm{O}_{4-\delta}$ Spinel Cathode Materials: A Systematic Study on the Effects of Li/Mn Ratio and Oxygen Deficiency. $J$. Electrochem. Soc. 2001, 148, A723-A729.

(34) Guo, C. X.; Wang, M.; Chen, T.; Lou, X. W.; Li, C. M. A Hierarchically Nanostructured Composite of $\mathrm{MnO}_{2} /$ Conjugated Polymer/Graphene for High-Performance Lithium Ion Batteries Adv. Energy Mater. 2011, 1, 736-741. 
(35) Tarascon, J.; McKinnon, W.; Coowar, F.; Bowmer, T.; Amatucci, G.; Guyomard, D. Synthesis Conditions and Oxygen Stoichiometry Effects on Li Insertion into the Spinel $\mathrm{LiMn}_{2} \mathrm{O}_{4}$. J. Electrochem. Soc. 1994, 141, 1421-1431.

(36) Laskar, M. R.; Nath, D. N.; Ma, L.; Lee II, E. W.; Lee, C. H.; Kent, T. K.; Yang, Z.; Mishra, R.; Roldan, M. A.; Idrobo, J. C.; Pantelides, S. T.; Pennycook, S. J.; Myers, R.C.; Wu, Y.; Rajan, S. P-type Doping of $\mathrm{MoS}_{2}$ Thin Films Using Nb. Appl. Phys. Lett. 2014, 104, 092104.

(37) Gao,Y.; Dahn, J. Synthesis and Characterization of $\mathrm{Li}_{1+} \mathrm{Mn}_{2-\mathrm{x}} \mathrm{O}_{4}$ for Li-Ion Battery Applications. J. Electrochem. Soc. 1996, 143, 100-114.

(38) Xu, J.; Chou, S. L.; Avdeev, M.; Sale, M.; Liu, H. K.; Dou, S. X. Lithium Rich and Deficient Effects in $\mathrm{Li}_{\mathrm{x}} \mathrm{CoPO}_{4}(\mathrm{x}=0.90,0.95,1,1.05)$ as Cathode Material for Lithiumion Batteries. Electrochim. Acta 2013, 88, 865-870.

(39) Tarascon, J.; Guyomard, D. The $\mathrm{Li}_{1+\mathrm{x}} \mathrm{Mn}_{2} \mathrm{O}_{4} / \mathrm{C}$ Rocking-chair System: a Review. Electrochim. Acta 1993, 38, 1221-1231.

(40) Masquelier, C.; Tabuchi, M.; Ado, K.; Kanno, R.; Kobayashi, Y.; Maki, Y.; Nakamura, O.; Goodenough, J.B. Chemical and Magnetic Characterization of Spinel Materials in the $\mathrm{LiMn}_{2} \mathrm{O}_{4}-\mathrm{Li}_{2} \mathrm{Mn}_{4} \mathrm{O}_{9}-\mathrm{Li}_{4} \mathrm{Mn}_{5} \mathrm{O}_{12}$ System. J. Solid State Chem. 1996, 123, 255-266.

(41) Xia, Y.; Yoshio, M. An Investigation of Lithium Ion Insertion into Spinel Structure LiMn-O Compounds. J. Electrochem. Soc. 1996, 143, 825-833.

(42) Cheng, F.; Wang, H.; Zhu, Z.; Wang, Y.; Zhang, T.; Tao, Z.; Chen, J. Porous $\mathrm{LiMn}_{2} \mathrm{O}_{4}$ Nanorods with Durable High-rate Capability for Rechargeable Li-ion Batteries. Energy Environ. Sci. 2011, 4, 3668-3675. 
(43) Chan, H.; Duh, J.; Sheen, S. $\mathrm{LiMn}_{2} \mathrm{O}_{4}$ Cathode Doped with Excess Lithium and Synthesized by Co-Precipitation for Li-Ion Batteries J. Power Sources 2003, 115, 110118.

(44) Jiang, R.; Huang, Y.; Jia, D.; Wang, L.; Wang, L. High-Capacity, High-Cycling Cathode Material Synthesized by Low-Temperature Solid-State Coordination Method for Lithium Rechargeable Batteries $\mathrm{Li}_{1+\mathrm{x}} \mathrm{Mn}_{2} \mathrm{O}_{4-\mathrm{y}} \mathrm{F}_{\mathrm{y}}$. J. Electrochem. Soc. 2007, 154, A698-A702.

(45) Liu, H.; Strobridge, F. C.; Borkiewicz, O. J.; Wiaderek, K. M.; Chapman, K. W.; Chupas, P. J.; Grey, C. P. Capturing Metastable Structures During High-Rate Cycling of $\mathrm{LiFePO}_{4}$ Nanoparticle Electrodes. Science 2014, 344, 1480.

(46) Sun, Y.; Zhao, L.; Pan, H.; Lu, X.; Gu, L.; Hu, Y. S.; Li, H.; Armand, M.; Ikuhara, Y.; Chen, L.; Huang, X. Direct Atomic-scale Confirmation of Three-Phase Storage Mechanism in $\mathrm{Li}_{4} \mathrm{Ti}_{5} \mathrm{O}_{12}$ Anodes for Room-Temperature Sodium-Ion Batteries. Nat. Commun. 2013, 4, 1870.

(47) Mukerjee, S.; Thurston, T. R.; Jisrawi, N. M.; Yang, X. Q.; Mcbreen, J.; Daroux, M. L.; Xing, X. K. Structural Evolution of $\mathrm{Li}_{\mathrm{X}} \mathrm{Mn}_{2} \mathrm{O}_{4}$ in Lithium-Ion Battery Cells Measured In Situ Using Synchrotron X-Ray Diffraction Techniques. J. Electrochem. Soc. 1998, 145, $466-472$.

(48) Greedan, J. E. Geometrically Frustrated Magnetic Materials. J. Mater. Chem. 2001, 11, $37-53$.

(49) Kim, J. S.; Kim, K.; Cho, W.; Shin, W. H.; Kanno, R.; Choi, J. W. A Truncated Manganese Spinel Cathode for Excellent Power and Lifetime in Lithium-Ion Batteries. Nano Lett. 2012, 12, 6358-6365. 
(50) Lee, H. W.; Muralidharan, P.; Ruffo, R.; C. Mari, M.; Cui, Y.; Kim, D. K. Ultrathin Spinel LiMn ${ }_{2} \mathrm{O}_{4}$ Nanowires as High Power Cathode Materials for Li-Ion Batteries. Nano Lett. 2010, 10, 3852-3856.

(51) Amatucci, G. G.; Pereira, N.; Zheng, T.; Tarascon, J. M. Failure Mechanism and Improvement of the Elevated Temperature Cycling of LiMn2 O 4 Compounds Through the Use of the $\mathrm{LiAl}_{\mathrm{x}} \mathrm{Mn}_{2-\mathrm{x}} \mathrm{O}_{4-\mathrm{z}} \mathrm{F}_{\mathrm{z}}$ Solid Solution. J. Electrochem. Soc. 2001, 148, A171A182.

(52) Chan, H.; Duh, J.; Sheen, S. Microstructure and Electrochemical Properties of LBOCoated Li-Excess $\mathrm{Li}_{1+} \mathrm{Mn}_{2} \mathrm{O}_{4}$ Cathode Material at Elevated Temperature for Li-Ion Battery. Electrochim. Acta 2006, 51, 3645-3651.

(53) Huang, S.; Wen, Z.; Yang, X.; Zhu, X.; Lin, B. Synthesis and the Improved High-Rate Performance of $\mathrm{LiMn}_{2} \mathrm{O}_{4} / \mathrm{Ag}$ Composite Cathode for Lithium-Ion Batteries Electrochem. Solid-State Lett. 2006, 9, A443-A447.

(54) Chiu, K. F.; Lin, H.; Lin, K.; Chen, C. Stability Improvement of $\mathrm{LiMn}_{2} \mathrm{O}_{4}$ Thin-Film Cathodes under High Rate and Over-Discharge Cycling. J. Electrochem. Soc. 2006, 153, A1992-A1997.

(55) Murugan, A. V.; Muraliganth, T.; Manthiram, A. One-Pot Microwave-Hydrothermal Synthesis and Characterization of Carbon-Coated $\mathrm{LiMPO}_{4}(\mathrm{M}=\mathrm{Mn}, \mathrm{Fe}$, and Co) Cathodes. J. Electrochem. Soc. 2009, 156, A79-A83.

(56) Barsoukov, E.; Macdonald, J. R. Impedance Spectroscopy: Theory, Experiment, and Applications, Wiley, Hoboken, NJ 2005; Chapter 3, pp 129-202.

(57) Chou, S. L.; Wang, J. Z.; Sun, J. Z.; Wexler, D.; Forsyth, M.; Liu, H. K.; MacFarlane, D. R.; Dou, S. X. High Capacity, Safety, and Enhanced Cyclability of Lithium Metal 
Battery Using a $\mathrm{V}_{2} \mathrm{O}_{5}$ Nanomaterial Cathode and Room Temperature Ionic Liquid Electrolyte. Chem. Mater. 2008, 20, 7044-7051.

(58) Li, B.; Xing, L.; Xu, M.; Lin, H.; Li, W. New solution to Instability of Spinel $\mathrm{LiNi}_{0.5} \mathrm{Mn}_{1.5} \mathrm{O}_{4}$ as Cathode for Lithium Ion Battery at Elevated Temperature. Electrochem. Commun. 2013, 34, 48-51.

(59) Jang, D. H.; Shin, Y. J.; Oh, S. M. Dissolution of Spinel Oxides and Capacity Losses in $4 \mathrm{~V} \mathrm{Li} / \mathrm{Li}_{\mathrm{x}} \mathrm{Mn}_{2} \mathrm{O}_{4}$ Cells. J. Electrochem. Soc. 1996, 143, 2204-2211.

Table of Contents Graphic
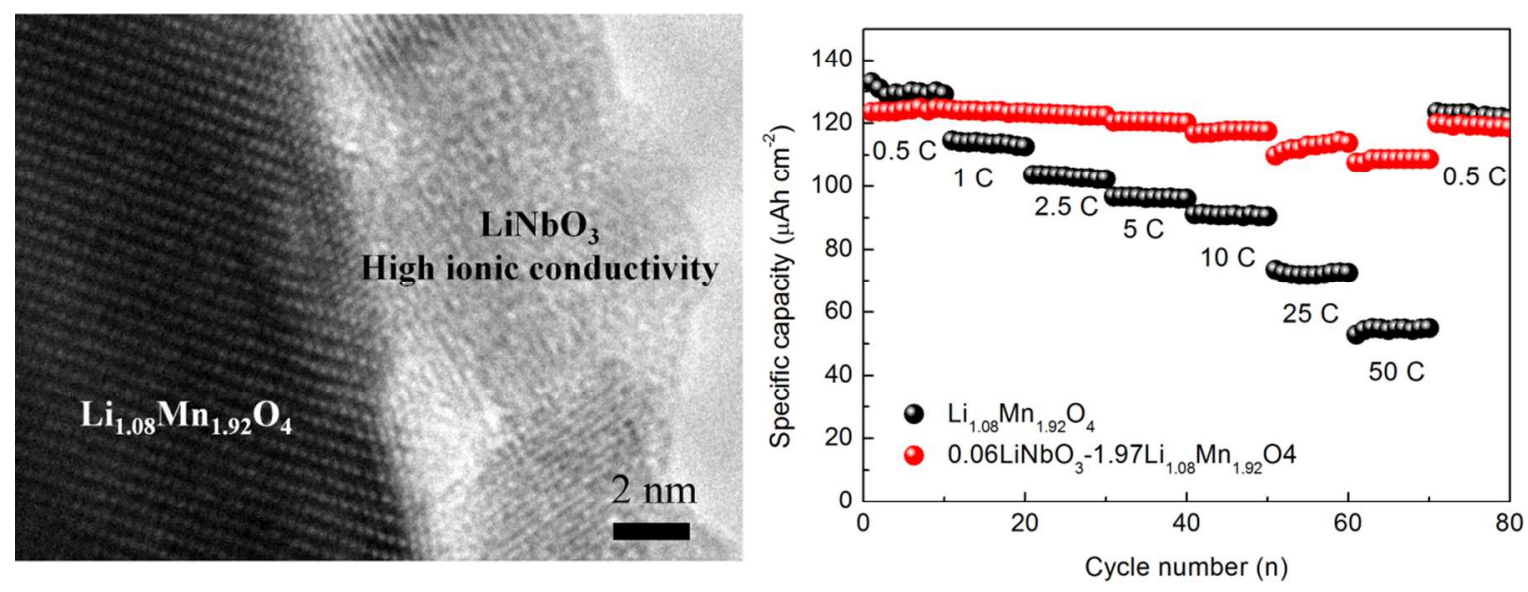